\title{
O Rosário e suas contas: redes associativas e cidadania de membros da Irmandade de Nossa Senhora do Rosário do Pelourinho (Salvador, 1880-1930 $)^{\mathrm{I}}$
}

\author{
The Rosary and its beads: associativists networks and citzenship of members of \\ the Brotherhood of Our Lady of Rosário of Pelourinho (Salvador, I880-1930)
}

\section{Mariana de Mesquita Santos*}

Resumo: A prática de filiação a irmandades negras e demais associações de apoio mútuo foi recorrente no século XIX entre africanos e afro-brasileiros. Muitas vezes ela acontecia como forma de acumular não só benefícios, mas também prestígio na sociedade. Na cidade de Salvador não foi diferente e alguns pesquisadores têm sublinhado essas redes associativas. Neste artigo, investigamos o perfil de alguns irmãos e irmãs da irmandade do Rosário às Portas do Carmo e analisamos os diferentes sentidos das proximidades estabelecidas entre membros da confraria com as sociedades mutualistas emergentes na capital baiana a partir da segunda metade do século XIX, bem como com outros espaços devocionais de matriz afro-religiosa. Com efeito, entendemos que as trajetórias de sujeitos associados à irmandade afro-baiana incluíam também o envolvimento com ativismos políticos e sociais do pós-abolição.

Palavras-chave: Pós-Abolição; Salvador; Associativismo negro.

\begin{abstract}
The practice of filiation to black brotherhoods and other associations of mutual support was usual between Africans and Afro-brazilians throughout the I9th century. Regularly, it constituted a way to accumulate not only benefits, but also prestige in the postabolition society. In the city of Salvador, it was not different, and some researchers have been underlining the relevance of those associationist networks. In this paper, we investigate the profile of some brothers and sisters of the brotherhood of Rosário às Portas do Carmo and analyze the different meanings of the closeness established between members of the brotherhood with the mutualist societies emerging in the capital of Bahia from the second half

\footnotetext{
${ }^{\text {I }}$ O presente artigo foi resultado de adaptação e atualização de dados e reflexões desenvolvidos em um dos capítulos da dissertação de Mestrado.

* Doutoranda do Programa de Pós-Graduação em História da Universidade de Brasília (PPGHIS-UnB). Bolsista do Conselho Nacional de Desenvolvimento Científico e Tecnológico (CNPq). Mestra, bacharela e licenciada em História pela Universidade de Brasília (UnB).
} 
of the Igth century onwards, as well as with other afro-religious spaces. We understand that the trajectories of subjects associated with the Afro-Bahian brotherhood also included involvement with post-abolition political and social activism.

Keywords: Post-Abolition; Salvador; Black Associationism.

Em seu livro, a “A Arte Culinária na Bahia”, publicado em 1922, Manoel Querino (I85I-I923) - intelectual negro e pesquisador baiano - revela alguns dos resultados de sua vasta pesquisa sobre a história da alimentação, que lhe demandou um profundo conhecimento sobre o seu estado, bem como diversas viagens por outras regiões do país. Com o objetivo de entender os processos, ingredientes e os sujeitos que elaboraram a tradição culinária da Bahia, o autor transitou entre "o norte e o sul do país, desde o Piauí ao Rio de Janeiro" (QUERINO, I922, p. 19) para realizar as suas investigações. A versatilidade e a circularidade de Querino na sociedade baiana do seu tempo lança luz sobre as possibilidades variadas de experiências vividas por pessoas negras, nos instigando a refletir sobre a viabilidade de outras experiências semelhantes às suas entre seus pares, bem como os discursos que povoaram seus diferentes ativismos e que o acompanharam por onde ele passou (LEAL, 2009, p. 20).

Se o seu trânsito ultrapassou as fronteiras do estado, podemos imaginar o quanto ele circulara na sua própria cidade, Salvador, seja para o seu ofício do desenho, ou para promover seu ativismo ou para buscar respostas às suas curiosidades. Estudos sobre a sua vida e obra apontaram que Querino ocupou cadeiras em associações de artífices, partidos políticos, blocos carnavalescos, associações religiosas cristãs e de matriz africana e no Conselho Municipal. Nesse sentido, sua figura habita um lugar inquestionável na história da Bahia e que precisa ser alocada nas grandes narrativas da formação do país.

Parte da sua memória pode ser explorada na Igreja de Nossa Senhora do Rosário dos Homens Pretos do Pelourinho, que abriga o seu jazigo. Sepultado em I923, sua ligação a esta confraria foi monumentalizada por este ato. Assim, a filiação de Manoel Querino também simbolizava as relevâncias social, política e cultural da confraria alocada no templo, herdadas da colonização e da escravidão, e que se reinventou no ocaso do Império. Apontar os sujeitos da Irmandade do Rosário dos 
Pretos às Portas do $\mathrm{Carmo}^{2}$ que deram vazão a diferentes debates na sociedade soteropolitana no pós-abolição lhe confere valor histórico, apesar da historiografia hegemônica que privilegiou a atuação das irmandades negras no contexto da colonização.

Somam-se a Manoel Querino dezenas de outros personagens, cujos nomes registrados nos documentos da burocracia desta e de outras agremiações, do Estado, jornais e outros documentos, nos permitem dar significado à atuação da confraria na passagem da escravidão para a liberdade e do Império para a República. Além disso, a irmandade negra abrigava africanas e afro-brasileiras, uma vez que a agremiação se definia pela composição por "pessoas de cor preta”. Com efeito, nos esquivamos de paradigmas que aliviaram a responsabilidade da produção historiográfica a respeito da liberdade negra por uma pretensa justificativa de ausência de fontes após o fim da escravidão (NASCIMENTO, 20I6, p. 609).

Neste trabalho apresentamos parte de uma pesquisa iniciada no Mestrado, que se concentra nas experiências de liberdade de irmãos e irmãs do Rosário às Portas do Carmo dentro e fora de seus espaços enquanto confraria na passagem do século XIX para o XX. A ideia é tomar esse grupo como ponto de partida para então traçar possíveis pertencimentos às dinâmicas sociais, políticas e culturais variadas do pós-abolição, apresentando os caminhos de pessoas que tinham na agremiação um de seus palcos e amparos em um contexto marcado pelas adversidades do racismo, romanização da Igreja, sexismo e marginalização para homens e mulheres de pele escura, mas também por complexidades e particularidades que podem extrapolar tais condições.

\section{Associativismos e coletividades negras em Salvador no Pós-Abolição}

A partir da análise de testamentos deixados por livres e libertos da Bahia na segunda metade do oitocentos, a historiadora Katia Mattoso observou uma queda no número de menções de filiação às irmandades. Neste período, com a ampliação da emancipação de escravizados e escravizadas, a multiplicação de associações

\footnotetext{
${ }^{2}$ Ao longo de sua existência, a confraria ficou conhecida por Irmandade de Nossa Senhora do Rosário da Baixa dos Sapateiros, às Portas do Carmo, e, a partir de I899, por Venerável Ordem Terceira de Nossa Senhora às Portas do Carmo.
} 
abolicionistas e mutualistas, o desestímulo pelas orientações ultramontanas, ${ }^{3}$ teria ocorrido um certo desgaste na relevância das irmandades. Nesse sentido, Mattoso aponta que apenas $15 \%$ dos testamentos de pessoas livres de Salvador do final dos oitocentos continham algum sinal de filiação às confrarias religiosas. Cenário distinto daquele do início do século XIX, cujos dados indicaram a filiação de 85\% dos/as testadores/as às confrarias (MATTOSO, 1992, p. 400-40I).

Para além do desestímulo eclesiástico à manutenção das irmandades e ordens terceiras, Mattoso ressalta que o maior interesse dos poderes locais em relação aos problemas sociais fez com que estes potentados criassem as suas próprias instituições de

socorro e caridade, ocupando as funções assistencialistas anteriormente exercidas por aquelas agremiações. Ademais, o abandono por parte das elites das antigas tradições festivas reduziu os seus financiamentos (MATTOSO, I992, p. 402).

Para a historiadora Sara Farias, as funções de caridade atribuídas às irmandades foram ressignificadas, uma vez que neste período "viver de caridade passou a ser sinônimo de ociosidade e de vadiagem" (FARIAS, I997, p. I6). No processo modernizador e laicizador, alguns antigos valores da caridade cristã foram sendo gradualmente banidos do imaginário republicano que mobilizou justamente o ideário da disciplina capitalista do trabalho, com ênfase na formação da mão de obra livre e nos valores do trabalho assalariado. Diante de uma sociedade racista e que associava a

\footnotetext{
3 "O ultramontanismo, no século XIX, se caracterizou por uma série de atitudes da Igreja Católica, num movimento de reação a algumas correntes teológicas e eclesiásticas, ao regalismo dos estados católicos, às novas tendências políticas desenvolvidas após a Revolução Francesa e à secularização da sociedade moderna. Pode-se resumi-lo nos seguintes pontos: o fortalecimento da autoridade pontifícia sobre as igrejas locais; a reafirmação da escolástica; o restabelecimento da Companhia de Jesus (I8I4); a definição dos "perigos" que assolavam a Igreja (galicanismo, jansenismo, regalismo, todos os tipos de liberalismo, protestantismo, maçonaria, deísmo, racionalismo, socialismo, casamento civil, liberdade de imprensa e outras mais)" (SANTIROCCHI, 20IO, p. 24). Na mais recente historiografia relativa às experiências clericais no Brasil do século XIX, tem se discutido sobre quão prático e limitante teria sido esse projeto reformista por aqui. Para Ítalo Santirocchi, por exemplo, pesquisadores teriam pesado a mão ao avaliar as mudanças projetadas no período como eminentemente "repressoras" das manifestações dos leigos. Para ele, teria se tratado mais de uma "reforma da Igreja Católica buscando uma identidade própria", que não diria respeito à uma intervenção eminentemente exterior, de Roma (SANTIROCCHI, 20IO, p. 33). Todavia, especialistas na experiência baiana têm apontado como as festividades leigas foram contidas pela intensificação da fiscalização clerical às confrarias, impondo um modelo que podava suas tradições, gerando conflitos (COUTO, 20I6, p. 92-94; STASI, 2017, p. 49-52). Decerto esta relação variou de região para região e não temos espaço para nos debruçarmos neste sentido. Em todo caso, é importante ponderar que, possivelmente, o processo não tenha sido mais transformador devido à persistência de confrarias que se impuseram e disputaram tais normas, munidas de seu poder adquirido pela tradição entre sujeitos da cidade.
} 
ociosidade e a vadiagem ao corpo negro, era importante para a irmandade do Rosário garantir que seus membros não assumissem a estigmatização a que lhes era imposta.

A despeito de valores "modernos" propagados por importantes instituições como a Faculdade de Medicina da Bahia e o Instituto Histórico e Geográfico da Bahia, que se alinharam ao pensamento eugenista (ALBUQUERQUE, I997, p. I8-39), e de pressões ultramontanas, de perseguições públicas contra práticas de matriz africana como os candomblés e a capoeira, a irmandade negra se preservou e se manteve como detentora de seu templo, sem grandes alterações em sua estrutura. Neste contexto republicano, complexo, dinâmico e tensionado pela convivência entre o novo e o antigo, entre modernidade e tradição, entre Igreja e Estado, entre diretrizes modernas e costumes antigos e escravistas, a confraria não só se manteve, como foi elevada à Venerável Ordem Terceira, o que lhe confere importância social, cultural e política junto à sociedade soteropolitana não apenas nos períodos colonial e imperial, mas também sob os reordenamentos da Primeira República.

Em carta encaminhada em I894, o escrivão Manoel Nascimento de Jesus justificava o pedido da elevação dos irmãos à condição de terceiros por sua dignidade, obediência às autoridades religiosas, boa localização de seu templo e por apresentarem reservas significantes de bens. ${ }^{4} \mathrm{O}$ pedido foi sendo atendido gradualmente, com a autorização para uso de "hábito, correia e capa como usam os terceiros de S. Domingos", concedida em I895..$^{\circ}$ O processo de oficialização não demorou a vir.

[...] faltava a oficialização, que somente em 1899 foi concedida por D. Jerônimo, no dia 2 de julho, significativamente a mesma data em que se celebra a Independência da Bahia. A partir de então ela gozaria de todos os privilégios e indulgências concedidas pelo Sumo Pontífice à Ordem Terceira da Penitência de São Domingos. Uma vez elevada a Ordem Terceira, um novo compromisso foi elaborado para substituir o último vigente, aprovado em I820. Segundo Edilece Couto, um dos maiores esforços de D. Jerônimo Tomé da Silva em sua atuação no Arcebispado Primaz foi o "trabalho lento e discreto para intervir e fiscalizar as irmandades e ordens terceiras sem fazer alardes" (COUTO, 2016, p. 92). O atendimento à solicitação dos confrades do Rosário para serem elevados à condição de terceiros pode ter sido uma forma amena de o arcebispo garantir um espaço de intervenção do

\footnotetext{
${ }^{4}$ AINSR. Caixa or Doc 09. "Requerimento de elevação para Ordem Terceira enviado ao Arcebispo, I894". ${ }^{5}$ Hemeroteca Digital da Biblioteca Nacional (HDBN). Leituras Religiosas - Publicação Semanal, (BA), 06/Io/I895.
} 


\section{C) Gitistórórica}

clero naquele espaço obtendo o respeito e a gratidão dos irmãos e irmãs pelo título alcançado (SANTOS, 20I8, p. 97).

O clero certamente reconhecia a importância da irmandade no contexto local. Além disso, Sara Farias assinala que havia por parte das autoridades civis o "medo do negro organizado depois da abolição" (FARIAS, I997, p. 82). Uma vez integrada a um cenário elitizado da sociedade, a Igreja também sinalizava, assim, uma medida de negociação com esses confrades e de acomodação de interesses.

O estudo acerca das formas associativas encabeçadas e voltadas aos interesses da população "de cor" ao longo da história tem crescido. Elas se apresentam como um profícuo panorama para traçar experiências e trajetórias afrodescendentes. Como nos indica a historiadora Ana Flávia Magalhães Pinto, estas análises se iniciaram a partir das narrativas acerca dos clubes e sociedades paulistas iniciadas no século XX, para depois se espalharem por outras direções, tanto em relação à dimensão temporal quanto espacial (PINTO, 20I4, p. 269).

Essas configurações se deram sob diferentes formas, como clubes sociais, associações beneficentes, jornais, blocos carnavalescos, agremiações recreativas, musicais, dramáticas, esportivas, organizações religiosas, etc. O historiador Jonatas Roque Ribeiro define, de modo geral, o que podemos entender por "associativismo negro":

[...] modo de reunião ou congregação de um grupo social negro. Pode também ser entendido como espaços, manifestações e valores que tem por objetivo a criação, ou manutenção, de vínculos de solidariedade, sociabilidade e beneficência entre aqueles que comungam identidades étnicas, raciais e culturais semelhantes (RIBEIRO, 20I6, p. I4-I5).

Ele salienta que devemos ter em vista que o conceito pode ser mais elástico, conforme o contexto em que se insere cada pesquisa (RIBEIRO, 20I6, p. I5). As irmandades negras, desde sua fundação na América Portuguesa, ${ }^{6}$ podem ser incluídas nesta definição. Afinal, um de seus pilares era o da assistência mútua entre os seus membros, com quem partilhavam a pertença étnica, racial, de gênero, devocional e cultural. Ao lado destas agremiações, a imprensa negra e as sociedades mutualistas despontaram como formas pioneiras de associações negras.

\footnotetext{
6 Historiografia relativa às irmandades negras, ver SCARANO (I975); RUSSELL-WOOD (I974);
} MULVEY (I980); BOSCHI (I986); QUINTÃO (I997); SOARES (2000); VIANA (2007); REGINALDO (20II). 


\section{C) GitistóñóRICA}

Entre o século XVII e XIX as irmandades negras se difundiram pelo Brasil.

Segundo o Atlas Histórico da América Lusa, nos setecentos as organizações do Rosário se distribuíram de forma impressionante de norte a sul, com mais intensidade no Nordeste e Sudeste (GIL; BARLETA, 20I6, p. 45). Na região Norte, onde a presença africana e afrodescendente foi bastante negligenciada pela historiografia, Patrícia Sampaio enfatiza que circular em Belém ou Manaus significava encontrar nas ruas diferentes sujeitos negros ocupando espaços variados, dentre eles "as festas do Espírito Santo, de Nossa Senhora de Nazaré ou ainda, membros da Irmandade do Rosário" (SAMPAIO, 2007, p. 5). Mais precisamente, o historiador Márcio Couto Henrique identificou devoções negras no Grão-Pará oitocentista espalhadas em diferentes regiões e com dinâmicas particulares, apresentando São Raimundo Nonato no bairro de Campina, em Belém, por exemplo, como a mais popular da cidade (HENRIQUE, 2009, p. 32). Nos surpreendeu que esse fosse um orago bem difundido entre os fiéis negros, já que essa não constava entre as devoções mais comuns em outras localidades, como N. Sra. do Rosário, São Benedito, Santo Elesbão ou Santa Efigênia (REGINALDO, 20II, p. 67-72).

As pesquisas dão indícios da dinamização da ereção de irmandades de pretos em outras territorialidades nordestinas além da Bahia, como Sergipe, Paraíba, Alagoas, Rio Grande do Norte e outras. ${ }^{7}$ De modo geral, suas experiências inserem mais sentidos para a compreensão do catolicismo leigo e negro no Brasil, que por vezes são mais analisados pelas trajetórias alocadas no Sul e Sudeste.

A imprensa foi uma das ferramentas apropriadas por intelectuais negros para veicularem suas reivindicações e articularem seus grupos em várias partes do país, desde o início do século XIX. Nosso protagonista do início do artigo, Manuel Querino, fundou o jornal A Província, em I887, que funcionou até o ano posterior, sintonizado às demandas do movimento de trabalhadores. Já em I892, ele editou o jornal O Trabalho, quando estava atuando na União Operária Bahiana (PINTO, 2006, p. 30; CASTELLUCCI, 2008, p. I03). Nesta mesma linha editorial, a publicação $A$ Voz do Operário, criada em I89I, contou com a participação como redator do mestre-de-obras negro Domingos Francisco Silva, que compôs a Irmandade do Rosário das Portas do Carmo. Este periódico serviu como "órgão oficial do Centro Operário da Bahia a partir de I894 e foi publicado até, pelo menos, I908" (CASTELLUCCI, 2008, p. 68). Mais

\footnotetext{
7 Sobre o assunto, ver: ARAUJO (2010); MACHADO (2020); SANTOS (2013).
} 
sintonizado à luta trabalhista de forma geral na Bahia e à luta por participação política, suas linhas não se atentaram especificamente à questão racial. Todavia, o protagonismo destes dois redatores foi significativo para a representatividade junto ao interesse de seus congêneres trabalhadores, artífices na sociedade soteropolitana.

Além da importância do produto impresso, o espaço de produção desses jornais se fazia a partir de sujeitos engajados em torno de projetos a favor das populações de cor, de forma que redes de solidariedade se delinearam a partir da sua redação e viceversa. Foi caso do jornal paulista $A$ Redenção, fundado pelo abolicionista Antônio Bento. A historiadora Antônia Aparecida Quintão afirma que este periódico "denunciava as injustiças, as misérias e as violências da escravidão e possibilitava o intercâmbio de informações entre os caifazes" (QUINTÃO, 2002, p. 80). Além de sucessor de Luiz Gama na presidência do Centro Abolicionista de São Paulo, Bento também foi provedor da Irmandade de Nossa Senhora dos Remédios, cujos salões deram espaço para a tipografia deste jornal. Com efeito, a sede da irmandade servia de ponto de encontro de membros de diversas irmandades, "que quase diariamente se encontraram para buscar informações, trazer notícias, apresentar sugestões e uma contribuição financeira para o movimento" (QUINTÃO, 2002, p. I04). Essa relação sugere que as irmandades não estavam totalmente distanciadas do movimento abolicionista. E, assim como Antônia Quintão detectou esta proximidade, provavelmente outros laços firmados podem ter sido feitos nos bastidores das confrarias em favor da abolição para não criar registros e alarde diante das autoridades estatais e católicas, preservando esta aliança.

Além da imprensa, a atividade de clubes sociais negros também teve relação com as irmandades negras. Liane Muller avaliou que a experiência da confraria negra serviu para o aprendizado destes sujeitos à prática da organização coletiva, ao assinalar que

(...) primeiramente em bases burocráticas determinadas pela instituição religiosa, mas logo a seguir, de forma quase colada à primeira, em um tipo de organização sub-reptícia cuja finalidade era pensar e executar estratégias capazes de dar uma nova feição ao homem negro inserido em um regime escravista.

As iniciativas desenvolvidas na Irmandade do Rosário contribuíram substancialmente para configurar esse grupo de homens [sic] enquanto um 


\section{C) Gitistórórica}

segmento social possuidor de capitais simbólico, intelectual e financeiro (MULLER, 20I3, p. IO8-IO9).

Os números obtidos a partir da pesquisa realizada por Muller indicam o envolvimento simbólico de irmãos e irmãs do Rosário de Porto Alegre com as entidades civis criadas entre 1870 e 1905. Dos 212 membros frequentemente encontrados nas fontes, 57 foram também localizados como fundadores e/ou diretores de entidades civis (MULLER, 2013, p. I09). Dentre os clubes sociais que a autora conseguiu identificar, nesta relação com a irmandade encontravam-se o clube Sociedade Floresta Aurora e a Sociedade Laço de Ouro. Esta última, com participação exclusivamente feminina, voltada para o amparo às meninas negras abandonadas ou em estado de pobreza absoluta (MULLER, 20I3, p. II8). Ao todo, entre I886 e 1930, Muller registrou a presença de 72 entidades de composição quase exclusiva de negros no Rio Grande do Sul, dentre sociedades dançantes, beneficentes e/ou instrutivas (MULLER, 20I3, p. I3I-I32).

O jornal $O$ Exemplo, fundado em I892, compôs essa tríade de organizações negras que se relacionavam entre si em Porto Alegre na passagem do século XIX para o século XX. Ele teve grande envolvimento com a divulgação das atividades das associações negras e seus projetos sociais da sua criação até I9Io (MULLER, 20I3, p. 168). Portanto, assim como o caso paulistano estudado por Antônia Quintão, o associativismo negro na capital gaúcha, segundo Muller, reunia a organização em movimentos civis, imprensa e uma irmandade negra.

Encontramos também vínculos estreitos das irmandades com agremiações de cunho classista. Em meados do século XIX, a Irmandade de São José do Ribamar, em Recife, exerceu importante papel para a organização de artistas mecânicos da cidade. Criada e gerida por homens de pele escura que perderam a possibilidade de se reunirem em corporações de ofício a partir de 1820 , a confraria pôde servir de alternativa para incorporar seus interesses de arranjo de classe e de manutenção de identidade social. Mesmo depois de fundarem a Sociedade dos Artistas Mecânicos e Liberais, seus membros acumularam as duas filiações. Inclusive, a sede da mesma associação foi abrigada por anos no consistório da irmandade de São José. Com efeito, revela-se que os dois tipos de agremiações continuaram coexistindo e agregando valor político, social e cultural nos embates travados na sociedade recifense, como nos mostrou a instigante pesquisa de Marcelo Mac Cord (2012, p, 76). 


\section{C) HitșTórRICA}

Assim, percebemos que há um contexto, no final do século XIX, em que as irmandades se mantiveram paralelamente às associações mutualistas emergentes em alguns casos e em outros não. O historiador Sidney Chalhoub (2007, p. 228) chamou atenção dos pesquisadores para a necessidade de se "interrogar que relações havia ou poderia haver, entre as irmandades religiosas tradicionais e as novas sociedades beneficentes" de meados do século XIX. Ele indaga, "ao considerar que as irmandades desempenhavam, desde o período colonial, funções de proteção social semelhantes às que passavam a definir as novas sociedades beneficentes, por que as últimas se tornaram cada vez mais comuns no Brasil da segunda metade do século XIX?". Chalhoub encontrou no estatuto de uma das mutualistas cariocas menção que sugeria a proximidade dela com a devoção à Nossa Senhora do Rosário. No caso soteropolitano, vimos que a proximidade das mutualistas com a irmandade foi muito evidente. Mas antes disso, é importante entender este movimento de conformação das associações mutuárias e a sua dinâmica identitária.

\section{Identidade, associações mutualistas e preservação das irmandades}

Em meados do século XIX, ao lado das irmandades preservadas, observa-se um grande movimento pela criação de sociedades mutualistas. Retirando as funções estritamente ligadas à devoção, estas associações tinham atribuições muito próximas às das confrarias por um lado e das corporações de ofício por outro. Elas eram criadas para garantir o auxílio aos respectivos membros em caso de desemprego, doença, invalidez, etc. Seus objetivos também se aproximavam daqueles propostos pelas antigas corporações de ofício, que atuavam na defesa dos interesses profissionais e regulamentação do exercício de cada ocupação (SILVA, I998, p. I9).

Havia também irmandades religiosas designadas por ofício. Na Bahia colonial, os ferreiros e serralheiros constituíram a Confraria de São Jorge, os sapateiros se reuniam na de São Crispim e os carpinteiros, pedreiros, canteiros e torneiros se reuniam sob a inovação de São José (FLEXOR, apud. REGINALDO, 20II, p. I20). Analisando a trajetória das agremiações fundadas por trabalhadores no Rio de Janeiro, o historiador Claudio Batalha defende que as associações mutualistas passaram a ser a forma associativa preferida pelos trabalhadores dos oitocentos por dois motivos. Em primeiro lugar, em decorrência da proibição impressa no texto constitucional de I824 
à conformação e à manutenção das corporações de ofício, uma das medidas liberais da constituição imperial (BATALHA, 1999, p. 49). E, em segundo, Batalha considera que a linguagem das antigas corporações já não mais atendia aos anseios dos profissionais e do mundo do trabalho de meados do século XIX (BATALHA, I999, p. 52), o que não representou a erradicação de lógicas similares às delas, como se revelou no caso investigado por Marcelo Mac Cord em Recife (MAC CORD, 20I2, p. 62).

Por conseguinte, trabalhadores recorreram às formas já disponíveis de associação para se reunirem em torno de uma causa comum, encontraram brechas na legislação ou inovaram na configuração de associações que fossem autorizadas. Paralelamente, no século XIX, as irmandades se mantinham como um recurso utilizado para o amparo social, haja vista a preservação de algumas daquelas que já existiam e a criação de novas. Por outro lado, trabalhadores lançaram mão de novas ferramentas associativas em busca do apoio em momentos de socorro e em defesa do seu exercício profissional: as associações mutualistas, sociedades de trabalhadores, montepios, as sociedades beneficentes e previdenciárias.

A partir de I860, a configuração destas associações seguia as prescrições do Decreto Imperial 2.7II, de 19 de dezembro e colocava o seu funcionamento sob a necessidade de aprovação do governo (SILVA, 1998, p. 38). ${ }^{8}$ Em levantamento realizado por Claudio Batalha, apresentam-se 46 sociedades de trabalhadores no Rio de Janeiro, criadas entre I835 e I899 (SILVA, I998, p. 57). Dentre elas, encontra-se montepios, cooperativas, sociedades beneficentes e mutualistas, em que a maioria se baseava na ideia de filiação para o apoio aos próprios membros. Grande parte delas também era composta por "artistas",9 operários e trabalhadores assalariados (BATALHA, I999, P. 59). Vale ressaltar que a necessidade não era o único motivo para

\footnotetext{
8 BRASIL. Decreto n ${ }^{\circ}$ 2.7II, de I9 de dezembro de I860. In. http://www.planalto.gov.br/ccivil_03/decreto/historicos/dim/DIM27II.htm. Acesso abr. 202I.

9 Neste período, entende-se por "artista" aquele que vive do trabalho manual, mas que, diferente do operário, seu ofício exige um embasamento histórico e filosófico, do qual sua obra retira referências para empregar o talento do autor. Nesse sentido, a historiadora Lysie Reis, enfatiza que o conceito de "artista" e "artífice" sempre estiveram imbricados na mentalidade do século XIX. Mas a vinculação da ideia de artista à necessidade do exercício da “inspiração e das faculdades creadoras”, que dava maior singularidade ao papel do profissional, acabava fazendo com que a denominação de "artista" fosse preferida por estes trabalhadores à de "artífice". Já que este último era entendido como "aquele que exerce um ofício mecânico, em que há regras deduzidas da experiência, tendo em vista uma utilidade "immediatamente prática". Ela aponta que, no caso brasileiro, dificilmente a definição estaria associada ao ensino formal de ofício já que no século XIX eram escassas as instituições de ensino destinadas às artes. Sendo assim, o termo abarcaria tanto aqueles que exerciam as artes liberais (letras, música, artes plásticas), quanto atividades mecânicas de confecção de produtos (chapeleiros, sapateiros, ourives, marceneiros, ferreiros, tipográficos, alfaiates, etc.). (REIS, 20I2. p. 23-3I; SILVA, I998, p. 23-25).
} 
estes sujeitos se associarem. Segundo o historiador Aldrin Castellucci, estudioso desta prática no contexto baiano, "em muitos casos, os fatores objetivos combinavam-se com os subjetivos, relacionados à construção de identidades" (CASTELLUCCI, 20Io, p. 43). Assim, a definição também poderia se dar pela vinculação a origem nacional, como ocorreu no Rio de Janeiro com a Congregação dos Artistas Portugueses, de I889 ou o Círculo Operário Italiano, de I895. Esse tipo de filiação foi muito recorrente em outras regiões do Brasil.

No mesmo local em que se registra a presença destas agremiações fundadas conforme a pertença nacional, houve tentativas de criação de sociedades beneficentes em favor da população de cor. Contudo, a reprovação das autoridades evidenciava o temor das elites diante das reuniões da população negra livre (CHALHOUB, 2007). A ideia defendida pelas elites de que a criação de organizações exclusivas para homens e mulheres negras é que ameaçaria "a harmonia e as boas relações entre os brasileiros" eximia da responsabilidade com a instituição escravista, esta sim catalisadora de grande parte das tensões sociais do século XIX. Ademais, a iniciativa daquelas pessoas em fundar uma associação baseada em critérios raciais evidencia a necessidade de criação de um espaço específico delas, até por conta da exclusão e do preterimento por parte dos brancos em relação à presença negra em seus ambientes. Assim como irmandades religiosas foram fundadas por africanos e afrodescendentes desde o século XVII porque não lhes eram permitidos o ingresso nas agremiações de brancos, tal condição não mudou tanto nos períodos posteriores com outros tipos de organizações.

Avaliações negativas de conselheiros que decidiam sobre a validação das associações evidencia o receio em relação à possibilidade da inversão da ordem social, em que ex-cativos pudessem tomar o poder senhores. Este temor se iniciou e se disseminou principalmente após a Revolução Haitiana, deflagrada em I79I $^{\text {,o }}{ }^{\text {e }}$ se mostrou, até certo ponto, justificado a partir da eclosão de rebeliões escravas nas primeiras décadas do século XIX. A Conjuração Baiana, em I798, e a Revolta dos Malês na Bahia, em I835, foram exemplares destas revoltas. Mesmo tendo sido sufocada pelas forças imperiais, a rebelião alertou o mundo todo acerca da potência de resistência e rebelião de africanos escravizados (REIS, I985; VALIM, 2007).

\footnotetext{
Io Insurgência da população escravizada, liberta e livre na então colônia francesa no Caribe de São Domingos, que resultou no primeiro Estado nacional oriundo desse tipo de revolta, primeiro país a abolir a escravidão e a segunda proclamação da independência nas Américas. Sobre o assunto, ver MOREL, (20I7).
} 


\section{C) Gițistórica}

A prática de associativismo foi muito importante para a formação do movimento operário no Brasil, embora não possamos considerá-la como experiência embrionária dos sindicatos. As associações atuavam mais no campo securitário, enquanto os sindicatos atuavam na esfera da produção e da proteção dos trabalhadores, lutando por maiores salários, melhores condições de trabalho para seus filiados, etc (CASTELLUCCI, 20I0, p. 4I). O desenvolvimento dos sindicatos se deu de forma paralela às associações mutualistas, de modo que estas continuaram a existir depois da conformação dos sindicatos. Mesmo assim, ao fim e ao cabo, quando lançamos luz sobre a experiência negra nas associações estamos contribuindo para a visualização da trajetória diaspórica em meio ao trabalho livre na Primeira República.

A historiografia que trata da trajetória dos trabalhadores neste período por muito tempo invisibilizou o recorte racial para entender a experiência do operariado. Para Chalhoub e Silva, isto se deu em grande medida devido ao distanciamento entre os historiadores sociais do trabalho e da escravidão, de modo que esta última acabou ficando como um capítulo externo à primeira (CHALHOUB; SILVA, 2009). Criticando o "paradigma da ausência" em defesa do "paradigma da agência" (CHALHOUB; SILVA, 2009, p. I4), os esforços de pesquisa têm se concentrado em contemplar as mais variadas formas de relações com o trabalho perceptíveis na experiência brasileira, tentando desviar-se das perspectivas eurocêntricas de se perceber a mão de obra livre." Isto porque, até meados do século $\mathrm{XX}$, as narrativas acabaram invisibilizando vários sujeitos, privilegiando as experiências que fossem próximas às dos trabalhadores do Velho Mundo, traçando uma narrativa que acompanhava a história do trabalho daquele continente e a sua linearidade, como se este fosse um modelo universal de desenvolvimento social (CHALHOUB; SILVA, 2009, p. 28).

Nestas mesmas narrativas, privilegiava-se a imagem do imigrante como figura preponderante e protagonista e, assim, as ideias sobre o trabalho livre no Brasil se construíram sob generalizações de práticas masculinas e brancas (CHALHOUB; SILVA, 2009, p. 4I). Até os anos oitenta, autores defendiam que a escravidão era um entrave à formação da classe operária no Brasil, desconsiderando que até o fim do regime do cativeiro havia escravizados que trabalhavam ao lado dos operários nas

\footnotetext{
II Sobre o assunto, ver: CHALHOUB (1990); FRAGA FILHO (2014); GOMES (2006); GRAHAM (2015); MATTOSO (20I6); MATTOS (2013); REIS; SILVA (1989).
} 


\section{C) HitcatóróRICA}

fábricas. Por outro lado, entendia-se que a condição de cativos não os colocava no mesmo campo de identificação de classe operária.

Segundo Álvaro do Nascimento, a historiografia hegemônica concentrada nos mundos do trabalho concebeu uma "ideia da incapacidade das pessoas escravizadas, que não lhes conferia o direito de serem chamadas de operárias, rótulo que até as crianças livres empregadas nas fábricas recebiam" (NASCIMENTO, 20I6, p. 6I3). Assim, a falta de menção à cor dos trabalhadores das fábricas e demais âmbitos do trabalho criou um imaginário de uma classe operária homogênea que, alinhada à ideia de que "após a Lei Áurea os egressos do cativeiro foram abandonados à própria sorte", excluiu os trabalhadores negros da História Social do Trabalho. Ignorou-se e construiu-se um silêncio em torno do fato de que esses trabalhadores negros haviam constituído a principal força laboral do país há séculos. Logo, essa mão de obra não deixaria de ter importância, sobretudo em locais onde a migração estrangeira não foi tão intensa, como na cidade de Salvador.

É importante buscar os espaços ocupados por estes atores para identificá-los em suas especificidades identitárias e de atuação. No caso da capital baiana, o historiador Aldrin Castellucci encontrou vinte e nove mutualistas de operários instaladas em Salvador entre I832 e I930 (CASTELLUCCI, 20ıo, p. 46-47), além de outras por vinculação a empresas e nação. Ao lado dos coletivos negros de cunho religioso, as organizações firmadas pelo vínculo de trabalho, como o Centro Opérario, o Montepio dos Artistas, e por cor/raça, como a Sociedade Protetora dos Desvalidos, nos ajudam a localizar os espaços de agência dos trabalhadores. $\mathrm{O}$ vínculo identitário imposto por algumas dessas associações nos permite perceber a fusão dos recortes de raça e classe. Nesse sentido, Nascimento sublinha que "as sociabilidades e experiências constituídas nas seletivas e hierarquizadas irmandades católicas e casas de candomblé, por exemplo, podem trazer à luz parte do legado das formas de organização e lutas negras para os/as trabalhadores/as do século XX" (NASCIMENTO, 2016, p. 620).

Com efeito, acreditamos que o envolvimento destes irmãos do Rosário nestes espaços evidencia que a irmandade não se constituía como um espaço religioso alheio às demais demandas sociais da comunidade trabalhadora negra soteropolitana. De modo que a presença de seus membros nas demais associações insere a referida ordem no debate das questões acerca dos direitos sociais, para além da sua ação comunitária direta e religiosa para seus membros de ambos os sexos. 


\section{"Geografia associativa" de membros da Irmandade do Rosário às Portas do Carmo}

Nas buscas no arquivo da Ordem Terceira do Rosário encontramos relatórios de atividades, convites, fichas de inscrição e outras correspondências que, associadas à historiografia, evidenciam o seu vínculo com associações mutualistas, irmandades, candomblés, blocos de carnaval, espaços de trabalho e de lazer. A carência de estudos, apontada também pela historiadora Lucilene Reginaldo, em relação aos contatos estabelecidos entre as irmandades e o associativismo negro no pós-abolição (REGINALDO, 20I8, p. 274), nos forçou a seguirmos os "fios de Ariadne", tendo os nomes como principal elemento de orientação (GINZBURG, 1994, p. I74-I75). Tal procedimento exige análises de fundos documentais muito extensos, por isso trata-se de um trabalho ainda em andamento. Registros que ainda não acessamos podem confirmar mais precisamente que nomes identificados em diferentes espaços correspondem ou não a homônimos. Contudo, levando em conta os casos que já foram apontados por trabalhos anteriores, bem como nomes que nos parecem menos comuns, conseguimos cruzar fontes e traçar percursos de pertencimento de diferentes sujeitos negros no pós-abolição a variados espaços, evidenciando experiências de sociabilidade compartilhadas e/ou específicas. ${ }^{12}$

A proximidade física das sedes é outro sinal do vínculo existente entre as associações soteropolitanas. Segundo Maria da Conceição Barbosa e Silva, várias sociedades congêneres tinham sede no Centro Histórico de Salvador, local onde também se encontrava a Igreja de Nossa Senhora do Rosário. Na Freguesia da Sé havia

\footnotetext{
I2 Para a organização e coleta desses nomes lancei mão de listas de membros do Centro Operário e da Sociedade Protetora dos Desvalidos (SPD) disponíveis nos anexos da tese de doutorado de Aldrin Castellucci e da dissertação de mestrado de Lucas Campos, respectivamente. Inclusive, alguns sócios destas agremiações já foram apontados por esses pesquisadores como membros da Irmandade. Acessei uma fonte diretamente do acervo SPD em que são registrados os nomes de I8o filiados entre I892 e I895. Dos arquivos da V. O. $3^{\mathrm{a}}$ do Rosário às Portas do Carmo analisamos $\mathrm{I} 5$ listas de composições e 20 termos de posse da mesa administrativa da confraria referentes ao intervalo de I888-I930; e 73I registros de entrada de irmãos e irmãs entre I888-I925. Tendo em vista a vastidão dessas listas, ainda não foi concluída a conferência dos rastros em outras fontes de todos/as ocupantes registrados/as. Espera-se que a conclusão da investigação sobre as irmãs registradas será feita na conclusão do doutorado em andamento, onde a experiência feminina é priorizada. Até o momento privilegiei o cruzamento dos nomes apontados em outras associações e contextos próximos pela historiografia, complementando com vestígios encontrados em outras fontes que acessei, como os jornais disponibilizados pela Hemeroteca Digital da Biblioteca Nacional. Organizei-os em tabelas e marquei aqueles/as que se vinculavam à Irmandade conforme a documentação que fotografei em seu arquivo e transcrevi. A disponibilidade digital dos trabalhos mencionados facilitou esse armazenamento, o qual pretendo ampliar com o retorno aos arquivos físicos baianos.
} 


\section{C) HitistóñICA}

o Montepio dos Artistas, a Sociedade Protetora dos Desvalidos, ambas com sede no Largo do Cruzeiro de São Francisco, o Centro Automobilístico da Bahia, na rua da Ordem Terceira de São Francisco, e o Liceu de Artes e Ofícios da Bahia, instalado na rua do Cruzeiro de São Francisco. Na Freguesia do Passo estava sediado o Centro Operário da Bahia, no Largo do Pelourinho, e a Sociedade Bolsa de Caridade, no Largo do Carmo. Além disso, outras agremiações menores, que não dispunham de instalações próprias, acabavam utilizando os cômodos cedidos por aquelas de maior prestígio (SILVA, I998, p. 9).

No caso do Rio de Janeiro, Claudio Batalha identificou que as sociedades de trabalhadores buscavam se instalar preferencialmente no centro da cidade, "afinal era o lócus privilegiado da política” (BATALHA, 2009, p. 260). Além disso, buscava-se "endereços em localizações relativamente prestigiosas, em ruas comerciais importantes" (BATALHA, 2009, p. 26I). Assim como o logradouro em que se instalava, era importante o estado de apresentação do imóvel.

\footnotetext{
As sedes não eram apenas o lugar de exercício principal da atividade associativa, o espaço de reunião dos membros ou de fornecimento de serviço aos associados. Era também uma das faces visíveis da associação na sociedade e, por isso, tanto a sua localização física quanto a sua arquitetura deviam funcionar como um monumento à própria associação e seus ideais, o que termina por dignificar seus associados (FONSECA, Apud. BATALHA, 2009, p. 265-266).
}

Nesse sentido, Batalha constatou que a classe trabalhadora não estava alheia ao discurso civilizador e europeizador das elites e das autoridades, mas "eles interpretaram o espaço à sua maneira e segundo seus interesses, não apenas por discursos, mas por práticas alternativas, imprimindo-lhe seus próprios valores" (BATALHA, 2009, p. 266). O historiador nomeia como "geografia associativa" a esse conjunto de práticas de apropriação do espaço urbano em nome dos interesses dos trabalhadores por meio da configuração de associações. Defendo que tal definição orientou o espaço associativo permeado pela irmandade do Rosário, buscando perceber seus agenciamentos a apropriações na sociedade soteropolitana a partir das redes associativas.

Assim como no caso observado no Rio de Janeiro, as associações baianas sediadas em Salvador tomaram, em certa medida, o espaço circundante aos centros de decisão política. A Câmara Municipal estava sediada também no Centro Histórico, 
onde, como apontado por Maria da Conceição Barbosa e Silva, estavam instaladas grande número das associações mutualistas da cidade. Em todo o estado, foram localizadas pelo historiador Aldrin Castellucci, I45 sociedades "autodenominadas como de auxílio mútuo, beneficentes, filantrópicas e cooperativas" fundadas entre os anos de 1832 e I930 (CASTELLUCCI, 20I0, p. 43), sendo que a maior parte delas funcionavam na capital.

Entre I888 e 1930, na lista dessas associações soteropolitanas, localizamos, pelas fontes encontradas no acervo documental da irmandade e pela historiografia relativa ao tema, algumas que foram mais próximas da Irmandade do Rosário dos Pretos, considerando a pertença mútua dos membros à confraria católica e às mutualistas. Eram elas a Sociedade Protetora dos Desvalidos (SPD), Centro Operário da Bahia, Sociedade Bolsa de Caridade, Sociedade Filarmônica (ou Musical) Guarani, o Liceu de Artes e Ofícios da Bahia e o Montepio dos Artistas.

Talvez o caso mais emblemático desta proximidade entre as associações, na passagem do século XIX para o século XX, seja o do intelectual, artista e político negro baiano, Manuel Querino. A historiadora Maria das Graças de Andrade Leal enfatiza a diversidade dos espaços percorridos por ele em sua trajetória de vida:

\footnotetext{
Se inter-relacionou com os universos da cultura popular, nos campos de lutas cotidianas estabelecidos nas ruas, terreiros de candomblé, associações artísticas e operárias, nos botequins, e da cultura erudita, nos espaços das instituições políticas - partidos e Conselho Municipal -, nos círculos letrados - academias, Instituto Geográfico e Histórico da Bahia, Colégios (LEAL, 2009, p. 44).
}

Tendo em vista a intensa circularidade deste irmão do Rosário, priorizamos sua biografia para começar a traçar esta geografia associativa. Ele foi um dos fundadores do Liceu de Artes e Ofícios da Bahia, da Escola de Belas Artes e do Centro Operário. Foi sócio da Sociedade Protetora dos Desvalidos e também presidiu o clube carnavalesco Pândegos d'África. Sua entrada na irmandade do Rosário foi registrada pelo escrivão Manoel Nascimento de Jesus entre os anos de I893 e I895 e em I92I. ${ }^{\text {I3 }}$

$\mathrm{Na}$ Sociedade Protetora dos Desvalidos, ele foi membro por longa data, chegando a atuar como caixa de empréstimos. Apesar de seu reconhecimento, a sua

${ }^{13}$ AINSR. "Termos de posse de novos irmãos" (I888-1920). Livro avulso. Folha I2I. "Composição da mesa administrativa de 1920 a I92I". Caixa Io Doc 06-D. 
presença nem sempre se deu de forma harmoniosa naquele cenário. Os atritos podem ter sido resultado de um desentendimento da Sociedade com Querino, resultante da insatisfação desta com o envolvimento do professor com a política institucional. Pois a SPD preferia se manter como autônoma, se apoiando nas autoridades apenas para garantir sua segurança financeira (BUTLER, 1998, p. I66). Ademais, seu comportamento em sociedade e os usos da associação não eram bem recebidos, como quando ele solicitou auxílio por enfermidade enquanto era visto nos festejos da cidade (CAMPOS, 20I8, p. 23).

Em I832, a SPD nasceu como a Irmandade de Nossa Senhora da Soledade Amparo dos Desvalidos. Ela foi erigida na Capela dos Quinze Mistérios e, em I848, passou a se instalar na Igreja do Rosário das Portas do Carmo, onde ficou por vinte anos. Mas as suas ligações parecem ser ainda mais antigas, o que se revela pelo fato de que, por pouco, o seu cofre não foi instalado naquela igreja já nos primeiros anos de vida da associação. Propuseram que o cofre fosse depositado "junto ao cofre dos Rosários ou cofre do Senhor dos Martírios" (BRAGA, I987, p. 25). O segundo cofre deve corresponder ao da confraria negra do Bom Senhor Jesus dos Martírios, sediada na Igreja da Barroquinha, que também integrava essa rede de espaços afro-religiosos em Salvador.

A partir de I85I, quando a SPD deixa de se definir como irmandade e passa a ser uma associação (BRAGA, I987, p. 3I), a pertença mútua a ela e à Ordem Terceira do Rosário (ou a outras confrarias religiosas) poderia funcionar como uma estratégia de combinação de benefícios religiosos e econômicos para o associado (BUTLER, 1998, p. I60). Kim Butler comenta que quando morreu Martinho Braga, membro da ordem e da associação, os Desvalidos assumiram os gastos do funeral e a confraria religiosa enterrou-o em uma de suas sepulturas. Uma vez garantidas as despesas do funeral, a irmandade do Rosário assegurava a sepultura em local de distinção, já que era detentora dos respectivos carneiros.

A sede da SPD funcionou nas dependências da Igreja do Rosário até I868. Segundo relatório elaborado pela mutualista, a associação teve de sair dali "depois de algumas desinteligências que teve com a Irmandade de Nossa Senhora das Portas do Carmo" (BRAGA, I987, p. 3I). A Sociedade se instalou em I887 na sede em que se encontra até hoje, um edifício próprio no Cruzeiro de Francisco. Seu prédio era considerado suntuoso para a época. Seu portal principal tem elementos em mármore, 
acabamento refinado, que denota seu alinhamento aos padrões estéticos das elites, mas apropriado aos interesses políticos e econômicos da comunidade negra.

A despeito dos motivos envolvidos na saída dos Desvalidos das dependências da Igreja do Rosário, a relação entre as duas agremiações teria se mantido estreita até o início do século XX, haja vista a presença de sócios nas fileiras da confraria. A partir do cruzamento de nossas fontes com os dados de filiados recolhidos pelo historiador Lucas Ribeiro Campos nos arquivos da SPD referente ao período entre 1880 e I899, encontramos 80 nomes que coincidiam com irmãos da Irmandade do Rosário detectados em todo o nosso recorte de pesquisa nos seus arquivos. Esse número corresponde a 21\% dos membros identificados por Campos (CAMPOS, 2018, p. I2O-I37). Há registros coletados da agremiação vizinha sem data, logo este número poderia ser ainda maior. $\mathrm{Na}$ busca dos arquivos da Ordem, também encontramos relatórios de atividades da SPD dos anos de I895 e I9I8, que também revelam esta proximidade. ${ }^{\mathrm{I}}$

A mudança de seu estatuto de irmandade para sociedade era um indício do processo de transformação e modernização das experiências associativas no Brasil e da classe trabalhadora emergentes a partir da segunda metade do século XIX. E, mesmo assim, como um processo histórico, ele se deu tensionado, eivado de rupturas e permanências, de modo que o desligamento da SPD como confraria religiosa não a afasta do catolicismo. Em sua sede no Cruzeiro de São Francisco há também uma capela dedicada a padroeira, Nossa Senhora do Amparo dos Desvalidos, onde eram celebradas missas em dias especiais. Aliado a isso, o engajamento de seus sócios na sociedade de irmãos do Rosário evidencia que o catolicismo rondava seu cotidiano. ${ }^{15}$ No caso do mundo do trabalho, a pesquisadora Lysie Reis também reforça a importância das heranças dos cantos de trabalho estabelecidos em Salvador ${ }^{16}$ para a criação de laços no serviço remunerado entre a população negra. A associação constituía "local propício ao encontro, circulação de ideias e ideais, como as negociações de remuneração, a competitividade entre os cantos, e as conspirações". E

\footnotetext{
I4 AINSR. "Balanço Geral dos Cofres da Sociedade Protetora dos Desvalidos. I9I7-I9I8". Caixa I8 Doc. OIA. p. 13 .

${ }^{15}$ Em documentário sobre a associação, a presidenta da SPD, a educadora Ligia Margarida, afirma que hoje há também um altar dedicado às entidades de matriz africana na sua sede. Porém não temos indícios para afirmar se ele esteve presente desde o final do século XIX. In.: "Nós Transatlânticos: Ligia Margarida - Associações, Irmandades e Desvalidos”, 20I7. (Disponível em https://www.youtube.com/watch?v=osXECcMewJs. Acesso jan/202I).

${ }^{16}$ Os cantos eram grupos de trabalho compostos por negros ganhadores, escravizados ou libertos, que se organizavam conforme a sua etnia ou "nação" (REIS, 2000).
} 
acrescenta: "a própria opressão que sofriam reforçou seus laços de solidariedade" (REIS, 20I2, p. 215-2I6).

Neste movimento de crescimento de mutualistas baianas, criou-se também a Sociedade Montepio dos Artificies, em I832. Ela era uma entidade laica e tinha como critério de agregação dos sócios os ofícios artesanais. Mesmo apresentando caráter secular, o catolicismo também se fazia presente nesta instituição, uma vez que foi escolhida uma padroeira para a associação, Nossa Senhora de Santana. Além disso, a preocupação com a garantia de sepulturas para seus membros repercutiu nas atribuições do Montepio, que possuía carneiros no Cemitério da Quinta dos Lázaros (CASTELLUCCI, 2010, 44-45).

De uma cisão nesta organização ocorrida em I852, um dos grupos discordantes da forma como era conduzida as suas contas foi expulso e criou a Sociedade Montepio dos Artistas. Sua base era predominantemente composta por ex-escravizados e seus descendentes, que exerciam atividades como carpintaria, sapataria, tipografia, marcenaria, etc. Mas, em I894, seu estatuto definiu que para ser admitido bastava ser profissional de alguma arte mecânica liberal, podendo ser até estrangeiro (SILVA, I998, p. 39). A predominância não-branca na associação nos revela a expressividade negra nessa área de atuação profissional (SILVA, I998, p. 28). Em I893, os sócios adquiriram a sede em que se encontra até hoje, no mesmo prédio, no Cruzeiro do São Francisco, muito próximo à SPD. Antes disso, alugavam um salão da Ordem Terceira de São Domingos (SILVA, I998, p. 58). A posse de sede própria e a localização certamente asseguraram algum relevo social e político no âmbito da cidade.

Nesta associação, encontramos vestígios da atuação do pedreiro Eloy Aleixo Franco. Ele era mais um desses trabalhadores negros que se destacaram atuando em diferentes associações, tanto de teor religioso, como a Ordem Terceira do Rosário, como de caráter mutualista, como a SPD e o Centro Operário. Em I893, o pedreiro se filiou aos Desvalidos. Em I898, foi eleito vice-presidente do Liceu de Artes e Ofícios. ${ }^{17}$ Atuou como tesoureiro, secretário e vice-presidente da União Filantrópica dos Artistas. Na Sociedade Mutualista dos Artesãos, ele serviu como tesoureiro mais de uma vez (BUTLER, I998, p. 159). E, em I9IO, Franco foi $2^{\circ}$ secretário do Montepio dos Artistas e, em I92I, foi presidente da mesma entidade (SILVA, I998, p. 6I). ${ }^{18}$ Esse

${ }^{17}$ HDBN. Jornal de Noticias (BA), 28/II/1898.

${ }^{18}$ HDBN. Almanak Laemmert, (BA), maio de i9Io. p. 64. 
percurso do pedreiro Eloy aponta-nos para a dinâmica de participação nas associações que não envolvia exclusividade; pelo contrário, havia um livre e múltiplo trânsito de uma mesma pessoa em diversas entidades associativas.

A Associação Liceu de Artes e Ofícios foi fundada em Salvador, no ano de I872, sob responsabilidade de vários artífices, como Manuel Querino. Ela foi criada a partir da iniciativa popular, para atender às demandas por modernização da força de trabalho da província da Bahia, nascendo com o intuito de promover o ensino teórico e prático às classes populares. As garantias previdenciárias também estavam inclusas em seus objetivos, buscando gerar "profissionais aptos a acompanhar a marcha do ambicionado progresso, e promover a beneficência aos seus sócios e famílias" (LEAL, 2009, p. 368). Até I874, o Liceu funcionou no edifício do Monte-Pio dos Artistas, evidenciando a rede estabelecida que já enfatizamos. ${ }^{19}$ Possivelmente, assim como Querino e Eloy Aleixo Franco, outros artistas membros da irmandade do Rosário se associaram e se beneficiaram da atuação do Liceu, haja vista tanto a similaridade de interesses e a recorrência da vinculação deste setor à confraria, como a proximidade geográfica dos locais em que a instituição funcionou.

O Centro Operário, cujos muitos personagens também estavam muito próximos à Ordem Terceira do Rosário, se inseria nesta rede do associativismo mutualista baiano, mas apresentava um espectro de ação mais amplo. Ele surgiu depois de duas tentativas das mesmas lideranças de tentar fundar, em primeiro lugar, o Partido Operário, para que concorressem às eleições para a constituinte de 1890 . No mesmo ano, o Centro viveu uma cisão interna, sendo que uma de suas dissidências deu origem a outra organização, a União Operária Bahiana. Em I893, todo o grupo inicial entrou em um acordo e assim foi fundado o Centro Operário como uma entidade mais unificada. Sua primeira sede funcionou em um prédio na antiga rua Direita do Palácio, onde hoje é a rua Chile, no centro histórico da cidade (CASTELLUCCI, 2008, p. 8I). Posteriormente, a entidade se instalou em um edifício no Largo do Pelourinho (SILVA, 1998, p. 9).

Pela trajetória de sua criação, os representantes do Centro Operário não tinham a pretensão unicamente de se reunir em torno do apoio mútuo aos trabalhadores,

${ }^{19}$ LICEU de Artes e Ofícios da Bahia (Salvador, BA). In: ENCICLOPÉDIA Itaú Cultural de Arte e Cultura Brasileiras. São Paulo: Itaú Cultural, 20I8. Disponível em: $<$ http:/enciclopedia.itaucultural.org.br/instituicaoI745I/liceu-de-artes-e-oficios-da-bahia-salvador-ba>. Acesso em: 25/0I/202I. Verbete da Enciclopédia. 
como a SPD ou o Montepio. Entre os seus objetivos estava o desejo de alcançar a representação da classe trabalhadora nas arenas da política institucional, uma vez que as mesmas lideranças haviam disputado cargos legislativos. Além disso, seus membros também atuaram no sentido de lutar por melhores condições de trabalho, "indicando a assunção, por parte dessa organização, de funções que seriam assimiladas, posteriormente, pelos sindicatos" (CASTELLUCCI, 20I0, p. 57).

Na constituição do Centro Operário da Bahia observa-se que a organização deveria oferecer aos seus membros cursos primários, secundários e técnicos. Com tal propósito, seus fundadores aprofundaram ainda mais o seu campo de atuação em relação às atividades das outras mutualistas, expressando sua preocupação com a formação técnica da classe trabalhadora, diante da modernização do mercado, e com a sua cidadania política, já que o voto era vetado aos analfabetos. Com a escolarização dos seus associados, seria possível angariar mais eleitores para a sua causa e a de suas lideranças. No ano de I898, o Centro apresentava uma escola primária diurna frequentada por cem alunos e uma noturna com sessenta estudantes, ${ }^{20}$ atendendo à diversidade de ocupações e de disponibilidade de seu público. O Centro Operário também oferecia assistência nos mais diversos sentidos, inclusive assistência jurídica para casos de litígios envolvendo operários (CASTELLUCCI, 20IO, p. 57-58). Embora já garantisse apoio mútuo aos seus membros, a organização se aproximou das irmandades e demais associações. Essa aproximação sinaliza para seu projeto político de ampliação do prestígio e reconhecimento público pela sociedade soteropolitana. Além disso, também indica que os espaços religiosos não estavam alheios às discussões relativas aos ativismos da classe trabalhadora.

Um anúncio da realização de uma missa na Igreja da Ordem Terceira do Rosário, em comemoração ao aniversário de dez anos do Centro Operário, ${ }^{2 \mathrm{I}}$ revela a ligação dos membros com a comunidade católica. Um dos atos comemorativos programados no anúncio foi a colocação de um retrato de um ex-governador da Bahia, em homenagem à sua memória. Esta aproximação com autoridades, estabelecida por meio de homenagens, pontua um elemento de negociação com as elites e autoridades em nome de proteção, apoio e reconhecimento social. Embora se tratassem de instituições da classe trabalhadora, muitos títulos foram concedidos pelas mutualistas

\footnotetext{
${ }^{20}$ HDBN. Jornal de Noticias, (BA), 19/03/1898.

${ }^{21}$ HDBN. Correio do Brazil: Orgão Democrata (BA), 06/05/1904.
} 
a representantes do Estado, um modo diplomático no sentido de assegurar e/ou manter subvenções recebidas e preservar certa distinção social.

Para isso, muitas dessas associações mantinham os títulos como o de "sócio protetor", "sócio benfeitor", ou o de "sócio honorário". Normalmente, eles eram destinados a pessoas com poder econômico, político, intelectual ou religioso. Segundo Lysie Reis, os sócios honorários não recebiam socorros e nem eram contemplados com cargos administrativos na associação, mas eram inseridos nas altas comissões e podiam fazer proposições nas assembleias. Estes títulos também poderiam ser concedidos a pessoas que prestavam serviços à sociedade, como professores, médicos, padres, etc (REIS, 20I2, p. 23I-232). Reis concluiu que esse tipo de relação se inseria nas práticas de "reciprocidade própria das trocas entre camadas subalternas e abastadas" estabelecidas em cenários de descaso das autoridades públicas com as necessidades dos estratos sociais, como classificou E. P. Thompson (REIS, 20I2, p. 234).

A família Fernandes Galliza, por exemplo, ocupou lugar como benfeitora de associações afro-baianas, como a Irmandade de Nossa Senhora do Rosário e a Sociedade Protetora dos Desvalidos. Benedito Fernandes Galliza era proprietário de escravos no início do século XIX e seu filho deixou para a Irmandade do Rosário três das suas seis casas (BUTLER, I998, p. I45). Na lista de sócios da SPD do final do século XIX constava outros membros da família, como Xavier Fernandes Galliza, que deve ter continuado o legado de beneficência de seus antepassados. ${ }^{22}$

A composição social dos Fernandes Galliza pode ter sido variável em relação às suas ocupações. Os registros deste sobrenome entre os/as filiados/as da irmandade perduram até o início do século XX. Izidro Fernandes Galliza, por exemplo, aparece como um irmão professo no ano de 1920 e servente no Ginásio da Bahia anos antes. ${ }^{23}$ Integrado indiretamente a uma certa intelectualidade, ele poderia estar sintonizado em relação aos seus direitos enquanto trabalhador e cidadão. O famoso rábula Cosme de Farias, então deputado estadual em 1915, defendeu na câmara legislativa o reconhecimento do tempo de serviço de Izidro no Ginásio da Bahia como servente, compreendido entre 1875 e I9I5, reivindicando a aposentadoria do funcionário. $\mathrm{Na}$ notícia se registra que ele foi um "funcionário exemplaríssimo e que nunca deu uma

${ }^{22}$ ASPD. "Lista de sócios de I892-I895". (Consultada no computador da Associação).

${ }^{23}$ AINSR. Listagem de Irmãos Professados (I920). Caixa IO, Doc. 7 . 
só falta [...] geralmente estimado e, apesar de alquebrado pelos anos, ainda cumpre

fielmente ali todos os seus deveres". ${ }^{24}$

Apesar de colocada em debate por diferentes movimentos sociais naquele contexto, ainda não havia uma legislação específica sobre previdência social que atendesse a trabalhadores de forma generalizada, o que também justifica a relevância do vínculo a agremiações de apoio mútuo. Contudo, a "excepcionalidade" de Izidro enfatizada pelo deputado Cosme Farias poderia lhe valer algum tratamento particular, ao mesmo tempo que a solicitação se mostra em consonância com demandas sociais mais amplas. Não sabemos qual foi o resultado do requerimento, mas a sua ligação à Ordem Terceira do Rosário sinaliza que esta pode ter sido a fonte de algum socorro, bem como a profissão religiosa pode ter ocupado o seu tempo no caso do afastamento das suas funções no Ginásio por sua idade já avançada.

Aldrin Castellucci destacou que, dentre os I.I76 associados do Centro Operário identificados, a cor de 127 deles foi registrada. E, destes I27, 98 eram não-brancos ${ }^{25}$ (CASTELLUCCI, 2008, p. I26). Levando em conta que esta amostra pode ser representativa de todo o corpo da entidade, resulta que $77, \mathrm{I} \%$ dos filiados correspondem à indivíduos negros, isto é, a maioria, como ressalta o historiador. Assim, mesmo sem se constituir como uma organização definida por uma pertença racial, como representante da classe trabalhadora baiana, a associação se fez predominantemente não-branca (CASTELLUCCI, 2008, p. 127).

Castellucci (p. 129) mostrou que muitos desses sujeitos atuavam em outras organizações, compondo uma "constelação associativa", formada por mutualistas e irmandades religiosas e aqui acrescento os candomblés como integrantes dessa rede. Em sua busca em inventários, o historiador encontrou 12 membros do Centro Operário que também eram filiados à Ordem Terceira do Rosário das Portas do Carmo

\footnotetext{
${ }^{24}$ HDBN. Jornal A Notícia, 08/06/1915. Grifo nosso.

${ }^{25}$ Sabemos que as terminologias utilizadas para identificar pessoas negras variam do período colonial até os dias de hoje (SANTOS, 2005). Na análise de Aldrin Castellucci, o historiador separou esses indivíduos conforme as denominações que aparecem nas suas fontes: "preto", "branco", "pardo", "mestiços". Como vasta historiografia tem apontado, todas essas terminologias eram atribuídas de forma carregada de sentidos e igualmente fluidas de contexto para contexto. Nas próprias irmandades elas serviam de mecanismo identificador e demarcador de papéis (REIS, I996; VIANA, 2007). Por questões de espaço, optei por não me aprofundar nas complexidades dessas classificações neste artigo. Ao passo que, salvo os identificados como "brancos", escolhi tratar todos como "negros", "pessoas de cor". Ou, como era tratado na definição da irmandade em questão e no respectivo compromisso de 1900, "pessoas de cor preta". O termo "não branco" também me pareceu adequado, na medida em que, neste contexto, esses não seriam outros a não ser os negros, haja vista a ausência de menções a indígenas ou outras classificações étnico-raciais exteriores ao que é entendido como "negro" nos grupos observados.
} 
(CASTELLUCCI, 2008, p. I30). Analisando os nomes listados nos anexos de sua tese e cruzando com as listas de membros e componentes da mesa da Ordem Terceira do Rosário do mesmo período, encontramos nomes exatamente equivalentes que aumentaria essa lista para 32 membros mutuamente filiados à Irmandade do Rosário e ao Centro Operário e/ou a suas organizações originárias - Partido Operário e União Operária Bahiana. Processo similar ocorreu com a análise de listas de sócios da SPD às quais tive acesso. Outros nomes nessa condição ainda podem continuar a serem constatados a partir de verificação em outras fontes, buscando também confirmar se os homônimos correspondem às mesmas pessoas.

Dos nomes confirmados pelo trabalho de Castellucci, temos o carpinteiro preto Tibúrcio Luiz Souto (I873-1955), que além da Irmandade do Rosário do Pelourinho compôs a Sociedade Protetora dos Desvalidos, foi dirigente do Sindicato dos Trabalhadores em Madeira e do Centro Operário da Bahia, membro da Sociedade Dezesseis de Julho e integrou o Comitê Central de Greve durante a paralisação geral de junho de 1919 em Salvador (CASTELLUCCI, 2008, p. I30-I3I). Na confraria do Rosário, atuou pelo menos oito vezes na mesa. ${ }^{26} \mathrm{Na}$ SPD, constou como sócio remido e membro da comissão fiscal no relatório de $1918 .{ }^{27}$ A sua trajetória no movimento operário e nas duas agremiações negras indicam que ele era uma pessoa de destaque na comunidade soteropolitana (Imagem I).

Domingos Francisco da Silva (Imagem 2), por sua vez, foi um mestre de obras que ocupou a presidência do Centro Operário nos seus primeiros anos de existência, fez sua entrada na confraria negra do Rosário em outubro de I892 (CASTELLUCCI, 2008, p. I3I; 99-I00)..$^{28}$ Ele participou da fundação do Círculo Católico da Bahia e foi irmão de outras duas irmandades negras, a de São Benedito e de Nossa Senhora da Conceição da Praia (CASTELLUCCI, 2008, p. 75; IO0). Deixou registros escritos de sua atuação como mobilizador da classe trabalhadora, como o "Manifesto aos dignos Artistas, Operários e Proletários do Estado da Bahia" (CASTELLUCCI, 2008, p. 45). Foi também capitão da Guarda Nacional e na República foi chamado para atuar como auxiliar de obras públicas da Secretaria de Agricultura, Viação e Obras Públicas, entre

\footnotetext{
${ }^{26}$ AINSR. "Termos de posse da mesa administrativa". Livro Avulso. "Irmãos que compõem a mesa administrativa de I9I4-I915". Caixa Io Doc 06-C. AINSR. "Atas avulsas". "Irmãos que compõem a mesa de I922-1923". Caixa Io Doc 06-F. "Irmãos que compõem a mesa de I927-1928". Caixa Io Doc 06-H.

${ }^{27}$ AINSR. "Balanço geral dos cofres da Sociedade Protetora dos Desvalidos. I9I7-I818". Caixa I8 Doc OIA.

${ }^{28}$ AINSR. "Livro de entrada de irmãos. I888-1920". (Livro Avulso). Folha 92.
} 


\section{C) GitistóñICA}

I896 e I898. Assim ele foi galgando reconhecimento e experiência que lhe permitiram ocupar cargos eletivos como o de juiz de paz, de membro da junta distrital de Santana e o de conselheiro municipal de Salvador (CASTELLUCCI, 2008, p. IOo).

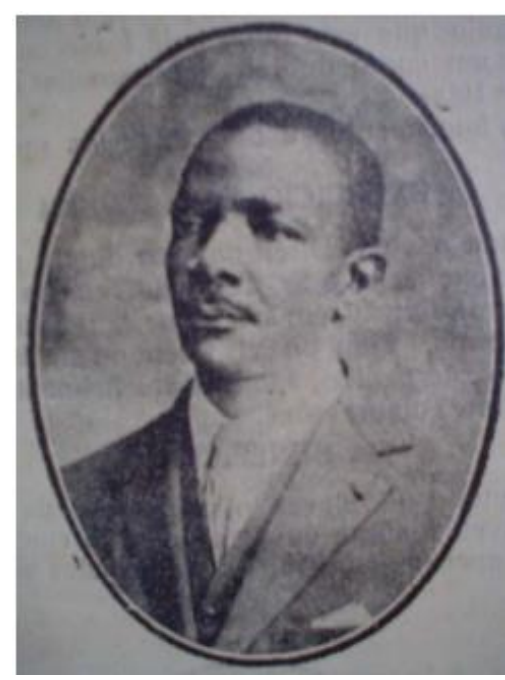

Imagem I. Tibúrcio Luiz Souto Fonte: Histórico e Relatório da Sociedade Protetora dos Desvalidos I832-1932. Apresentado pelo Presidente do Diretório Juventino Silvino da Costa. Aprovado em Assembléia Geral de 7 de setembro de I934. Exercício de I93I-I934 Bahia, I934. Apud. CASTELLUCCI, 2008. p. I3I.

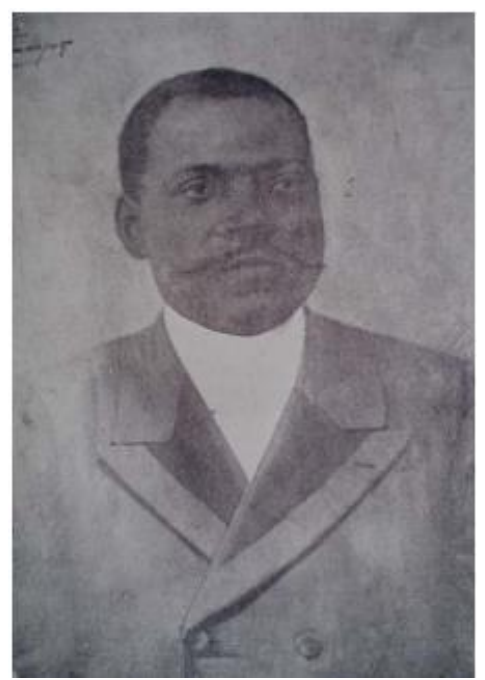

Imagem 2. Domingos Francisco Silva

Fonte: Associação Centro Operário da Bahia. Relatório (Exercício 1949-1950). Salvador: Imprensa Oficial da Bahia, I950. Apud. CASTELLUCCI, 2008. p. 5I

Faustino Gomes da Silva também era artista e ocupou por várias vezes o cargo de Secretário e outros da administração na Ordem Terceira do Rosário. A sua primeira passagem pela mesa, segundo os documentos analisados, se deu na década de I890, voltando a aparecer nos próximos vinte anos algumas vezes. ${ }^{29}$ No Centro Operário, atuou três vezes como dirigente, também foi membro da União Filantrópica dos Artistas e da Sociedade Protetora dos Desvalidos (CASTELLUCCI, 2008, p. I32-I33).

Manoel Friandes, pedreiro e capitão da Guarda Nacional também figurou entre os quadros da ordem da Baixa dos Sapateiros, da SPD e do Centro Operário. Analisando seu inventário, Castellucci identificou que além daquela irmandade,

29 AINSR. "Termos de posse de novos irmãos" (I888-I920). Livro avulso. "Composição da Mesa Administrativa de I9I8". Caixa I8 Doc oI-A. "Irmãos que compõem a mesa de I920". Caixa Io Doc o6-D. "Irmãos que compõem a mesa de I923-1924". Caixa Io Doc 06-F. 
Friandes também legou bens à Irmandade dos Quinze Mistérios, Irmandade do Rosário do João Pereira da Freguesia da Vitória e à Irmandade da Conceição do Tororó. Embora participasse de várias confrarias, pedia explicitamente em seu inventário que seu enterro ficasse ao cargo da Ordem Terceira do Rosário (CASTELLUCCI, 2008, p. I32). Com perfil similar, o empreiteiro e capitão da Guarda Nacional José Maria da Conceição figurou na nossa confraria e no Centro Operário (CASTELLUCCI, 2008, p. 133). Ao que nos parece, sua atuação na ordem pode ter sido acompanhada pela filiação de sua filha, Olga Lídia da Conceição, cujo nome aparece também na lista de irmãs professadas no ano de $1920 .{ }^{30}$ Gostaríamos de encontrar mais provas para atestar com maior convicção que esta médica, filha do empreiteiro preto, integrou o cotidiano da irmandade. A presença de seu pai, que lhe deixou um valioso espólio, atesta a diversidade social das fileiras da ordem, bem como lança luz para a presença de mulheres negras, ainda que limitada, em ofícios de distinção social como a medicina na capital baiana no início dos novecentos (CASTELLUCCI, 2008, p. II4II5).

Friandes figurou na mesa administrativa por várias vezes, o que indica que ele tinha posição relevante na agremiação. ${ }^{31}$ Segundo Kim Butler, ele também compôs o Montepio dos Artistas e a Irmandade de São Benedito, tendo organizado uma festa tão grandiosa que, segundo relatos, nunca foi vista outra igual (BUTLER, I998, p. I56-I57). Podemos perceber que era comum que estes sujeitos que transitavam entre vários coletivos não só os compunham, como também assumiam funções burocráticas e tinham grande reconhecimento nos coletivos.

Outro pedreiro, Affonso João Maria de Freitas, ocupou diferentes cargos na administração da Ordem do Rosário, sem deixar de se dedicar à Protetora dos Desvalidos. Apesar do engajamento, Butler encontrou vestígios que apontam para irregularidades cometidas no cuidado com a tesouraria do Rosário, que na sucessão do cargo levou a tensões dentro da Ordem. Para além de uma possível má gestão dos recursos promovida por Freitas, aquele também foi um período de "vacas magras" para

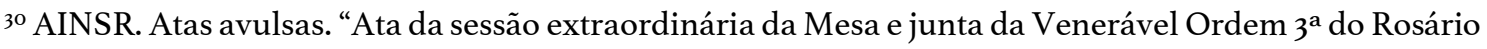
de Nossa Senhora das Portas do Carmo (OI/II/I92I)".

${ }^{31}$ AINSR. "Eleições I889". Caixa II Doc 03-K. "Eleições I890". Caixa II Doc 03-L. "Eleições da Irmandade de Nossa Senhora do Rosário das Portas do Carmo para o ano de I892" (Livro Avulso. Sem paginação). "Eleição I893". Caixa II Doc 03-N.
} 
a irmandade, o que aumentava as preocupações em relação a sua sobrevivência e a necessidade de ampliar sua base de membros (BUTLER, I998, p. I52-I53).

Outro espaço da cidade que contou com Manuel Querino foi o clube carnavalesco Pândegos d'África, onde ele aplicava seus conhecimentos sobre o continente africano para sugerir e/ou organizar os desfiles do bloco no carnaval baiano (ALBUQUERQUE, 2009, p. 217). Este clube foi fundado também com a participação de Bibiano Soares Cupim, sujeito ativo que transitou por muitos espaços em Salvador. Segundo a historiadora Wlamyra Albuquerque, seu currículo era bastante amplo: açougueiro, capitão da Guarda Nacional, banqueiro de jogo do bicho, carpinteiro, membro da Sociedade Protetora dos Desvalidos e da Irmandade da Boa Morte, ogã do terreiro do Gantois (ALBUQUERQUE, 2009, p. 220). Não só atuava nas agremiações, como ocupava posições de destaque nestes grupos. Na SPD figurou como presidente em 1918. ${ }^{32} \mathrm{Na}$ Ordem Terceira do Rosário esteve na mesa administrativa nos anos de I907, I908, I920, I92I, I922, I927 e 1928.33 Chegou a exercer os cargos de Procurador Geral, Definidor, suplente do Vice Prior e Prior (em 1907) (BUTLER, 1998, p. 139). Butler registrou ainda que ele foi vice-presidente do Centro Operário em 1926. Seu engajamento nestes espaços, bem como a condição de proprietário de alguns imóveis na cidade, indica que ele era um representante da comunidade afro-baiana de expressividade social e política em Salvador no pós-abolição, como destacou Albuquerque (ALBUQUERQUE, 2009, p. 22I).

O historiador Eric Brasil Nepomuceno também identificou essa configuração de uma rede negra, constando clubes carnavalescos, terreiros de candomblé, manifestações de trabalhadores e a Igreja de Nossa Senhora do Rosário e São Benedito na cidade do Rio de Janeiro, na década de i9ıo. O Club Liga Africana foi fundado por João Martins, o babalorixá conhecido como João Alabá de Omulu (NEPOMUCENO, 20I3, p. 7). Ele registrou o envolvimento deste clube com a organização de uma manifestação em homenagem à fundação de uma vila operária e também assinalou que, na ocasião da morte de seu fundador, os associados mandaram rezar uma missa em nome de sua alma na Igreja de Nossa Senhora do Rosário e São Benedito da capital fluminense. Para o historiador, esta rede “demonstra que a população negra da cidade

\footnotetext{
32 AINSR. "Balanço geral dos cofres da Sociedade Protetora dos Desvalidos". Caixa I8 Doc I-A. p. 23. 33 AINSR. "Lista de irmãos que compõem a mesa de 1908-1909". Caixa io Doc. o6-A. "Irmãos que compõem a mesa de I920-I92I". Caixa Io Doc 06-D. "Irmãos que compõem a mesa de I927-I928”. Caixa Io Doc 06-H.
} 
do Rio de Janeiro buscava expandir suas alternativas de atuação no espaço público ao mesmo tempo em que reforçavam que tipo de presença e performance deveriam exercer" (NEPOMUCENO, 20I3, p. 8). Ao nosso ver, em Salvador a estratégia era muito semelhante.

Não tivemos acesso à lista de componentes da Sociedade Musical Luso Guarani. Mas as notícias que registram a realização de reuniões e demais atividades das associações de trabalhadores informam que repetidamente a sede desta filarmônica recebeu encontros de trabalhadores. A relação dessa sociedade musical com a Irmandade do Rosário parecia ser estreita, pois nos anos de I89I e I892 seu nome figurava entre a lista de componentes da mesa administrativa como Protetor. ${ }^{34} \mathrm{E}$ provável que os espaços físicos da ordem e os serviços artísticos da banda tenham sido permutados em reuniões e festividades. Aldrin Castellucci mencionou vários encontros do Partido Operário (grupo cuja dissidência deu origem posteriormente ao Centro Operário) que foram realizados no salão da Filarmônica Luso Guarani (CASTELLUCCI, 2008, p. 56-59).

\section{Mulheres, "dupla pertença religiosa" e outras extensões da "geografia associativa"}

Neste estágio da pesquisa, esperamos encontrar mais nomes femininos registrados nos documentos da irmandade em questão que ecoem em outras agremiações próximas a ela. Analisando a historiografia em busca destes dados, inferese que os coletivos associativos com evidências de protagonismo das mulheres negras na Bahia foram os espaços religiosos das irmandades e dos candomblés. Como beneficiárias de associações, seu proveito ia mais além, era o caso das meninas órfãs, escravizadas ou filhas de escravizados integraram a Casa da Providência, onde recebiam instrução e educação já no fim do regime de cativeiro (CONCEIÇÃO, 20I3, p. 2I). Em Salvador, outras experiências de mulheres na posição de beneficiárias, e não como sócias propriamente ditas, foram identificadas. Assim, importa-nos pensar as irmandades como relevante espaço de agenciamentos femininos negros na capital baiana, de modo que seu compromisso e seu cotidiano lhes valia atribuições significativas nesta comunidade, a despeito da vedação de associações a sua

34 AINSR. "Eleição I89o". Caixa II Doc 03-L. "Eleição irmandade de Nossa Senhora do Rosário das Portas do Carmo para o ano de I892". (Livro Avulso). 


\section{C) HițTó ÓRICA}

participação, conforme avaliamos a seguir, dialogando com os apontamentos registrados pelas pesquisas atinentes aos associativismos dos mundos do trabalho na Bahia.

Em maior ou menor medida, os trabalhos que se debruçaram sobre as irmandades, associações negras não deixaram de lançar luz sobre as especificidades das experiências das irmãs em seus estudos. ${ }^{35}$ Por outro lado, quando analisamos a circularidade que homens como Manoel Querino demonstraram ter porta afora da Igreja do Rosário no final do século XIX da Bahia, sobretudo nos mundos do trabalho e do associativismo, nos pareceu razoável questionar se haveria relações das irmãs com outros tipos de construção de coletividade organizada de Salvador. Por exemplo, João José Reis aposta que, no final do século XVIII, as mulheres estariam inseridas nos cantos de trabalho. Pois a regulação das ganhadeiras constava no livro de posturas da cidade, mas a falta de matrículas do sexo feminino nos anos seguintes levou o historiador a crer que elas acabaram afastadas dos cantos (REIS, 20I9, p. 83-84). Teria algum efeito sobre elas a convivência com a experiência dos irmãos em outras associações ou o conhecimento de uma possível experiência feminina pregressa de organização, como os cantos? Temos nos empenhado na busca por essas respostas no doutorado. Por ora, a trajetória de irmãs no campo da religiosidade de matriz africana já nos apresenta ricas evidências da amplitude da sua ação coletiva.

O exemplo da ialorixá Eugênia Anna dos Santos (I869-1938), Mãe Aninha, é um caso visível e registrado da filiação mútua praticada por mulheres negras de Salvador, cujas redes alcançaram até a então capital federal. Criadora do Ilê Axé Opô Afonjá no Rio de Janeiro e em Salvador, Mãe Aninha, Obá Biyi, ocupou cargos na mesa administrativa da confraria, ${ }^{36}$ residia próximo ao seu templo, onde ela também foi velada (SANTOS, 2007, p. 266). Não se pode ignorar os fundamentos sociais e políticos do prestígio da ialorixá em uma cidade negra como Salvador. Ao seu redor compunhase uma rede de relações pessoais, que envolvia o candomblé de mãe Aninha e outros congêneres, tecida em meio às trocas de favores, de apoios, de algumas soluções encontradas pelas mediações de suas rezas e demais agenciamentos religiosos, que acomodou também a Irmandade do Rosário.

\footnotetext{
35 Sobre o assunto ver: FARIAS (I997); KARASCH (2012); SILVA (20I7); SOARES (200I). Para a experiência do século XX tardio, ver: SANTANA (2013).

36 AINSR. "Irmãs que compõem a mesa de 1927/1927". Caixa Io Doc 06-G.
} 


\section{C) GitistóñóRICA}

Butler identificou outra atuante participação feminina, a de Joana Maria Ritta da Conceição. Filha de africana, que, como irmã do Rosário das Portas do Carmo, foi eleita para a mesa pelo menos três vezes..$^{37} \mathrm{Na}$ irmandade da Boa Morte, atuou novamente como juíza e também fez parte de outras confrarias, legando bens não só para a Ordem Terceira do Rosário, como também para a irmandade de Senhor Bom Jesus dos Martírios da Barroquinha, Santa Bárbara do Corpo Santo, São Benedito e São Vicente Ferrer (BUTLER, 1998, p. 157).

A historiografia local nos informa que muitas mulheres africanas e afrobrasileiras tinham grande importância econômica no abastecimento da cidade, desenvolvendo atividades comerciais, o que lhes permitiu deixar propriedades para as confrarias (OLIVEIRA, I988, p. 34). No entanto, as organizações mutualistas não parecem ter contemplado estas trabalhadoras como associadas ou elas não optaram por essa forma de organização. No caso da SPD e do Montepio dos Artistas, por exemplo, as mulheres figuravam apenas como beneficiárias por serem esposas ou filhas de associados, apesar de tentativas de proposições da parte destas senhoras (CAMPOS, 20I8, p. 36). Como a maioria das associações eram voltadas para os artífices, deduz-se que existiam poucas mulheres dedicadas a essas atividades e, por isso, de sua baixa representatividade nestas instituições (BATALHA, I999, p. 65). Julgando ser incontornável uma pesquisa que investigue atentamente essa suposta ausência da presença feminina nas associações mutualistas e nos ambientes de trabalho em Salvador e no Brasil como um todo, venho buscando ampliar esta análise em pesquisa de doutorado em andamento.

Castellucci avalia que a exclusão das mulheres do Centro Operário deve ser creditada às suas pretensões eleitoreiras do grupo. Como elas só adquiriram esse direito ao voto em 1932, as trabalhadoras teriam sido excluídas do espectro associativo desta agremiação na Primeira República (CASTELLUCCI, 2008, p. I29). Uma exclusão que reforça nossa avaliação acerca da misoginia e do sexismo operante naquela sociedade.

Significativamente, o estatuto de sócias foi vetado às trabalhadoras de Salvador em outras agremiações mutualistas, mesmo daquelas sem intenções eleitorais, como o Montepio dos Artistas e a SPD. No caso do Centro Operário, essa exclusão explícita em

37 AINSR. "Eleição I890". Caixa II Doc 03-L. "Eleição irmandade de Nossa Senhora do Rosário das Portas do Carmo para o ano de I892". (Livro Avulso). "Eleição I893". Caixa II Doc 03-N. 
relação à participação feminina confirma-se também por uma de suas pautas de luta: o combate ao emprego de mulheres casadas e viúvas (CASTELLUCCI, 20I0, p. 83). Esse projeto reforça o pertencimento expressivo de mulheres à classe trabalhadora baiana haja vista a tentativa de interrupção de suas atividades. Por outro lado, a defesa da restrição do trabalho às casadas e viúvas é um indício da visão patriarcal do grupo, o que se repete com a interdição do ingresso de mulheres de forma autônoma em algumas mutualistas baianas. Levando em conta o elevado índice de mulheres das classes populares que sustentavam sozinhas as suas famílias, ${ }^{38}$ a falta de abertura dessas organizações certamente fez com que essas trabalhadoras mantivessem e/ou reinventassem as suas estratégias próprias de apoio coletivo do período da escravidão, tais como as irmandades negras, ou até mesmo criassem outras.

Na Sociedade dos Artistas Mecânicos e Liberais de Recife as mulheres também não tiveram vez. Segundo Marcelo Mac Cord, seu estatuto de I84I registra a preocupação dos sócios em se manterem antenados aos preceitos do "progresso" da força de trabalho na capital pernambucana, que os inclinou a vedar-lhes o acesso em nome do reconhecimento social da associação. Mas os assentos na irmandade aliada de São José do Ribamar continuaram assegurados a elas (MAC CORD, 2012, p. 77). Assim, do consistório da irmandade, elas asseguravam essa alternativa associativa.

Os clubes negros fundados na virada do século XIX e XX contaram com maior espaço para as mulheres. No Rio Grande do Sul, a Beneficente Laço de Ouro, organizada só por sócias, dedicou-se a amparar meninas negras desassistidas (MULLER, 20I3, p. II8). No Rio de Janeiro, Leonardo Affonso Pereira encontrou regimentos de clubes dançantes negros, como o da União das Borboletas, que abria suas fileiras às mulheres, sem exigir estatuto de casamento, possibilitando a vinculação autônoma tal como permitia-se aos homens (PEREIRA, 2020, p. I4O-I4I). Houve também aquelas que contaram com fundadoras, como a sociedade Rosa Branca (PEREIRA, 2020, p. 66). Exemplos como estes têm sido revelados por pesquisas

\footnotetext{
38 "O estrangulado mercado de trabalho baiano e a força da tradição não brindaram essas mulheres com maridos que provessem o sustento do lar. Ao contrário, em debandada os homens parecem fugir no período de 1872 a 1940, num verdadeiro êxodo, em busca de melhores chances profissionais em outras regiões. Em 1924, numa significativa amostra de 3.09I crianças lactantes ou em idade pré-escolar matriculadas nos órgãos de assistência à infância pobre da Inspetora de Higiene Infantil da capital baiana, 54,28\% eram ilegítimas [prole nascida fora de um casamento]. Do total geral dos matriculados, $31,28 \%$ tinham pais desempregados ou ausentes. As mães economicamente ativas perfaziam um total de 94,I7\%. Tal dado nos demonstra que em plena República o parto ainda continuava seguindo o ventre [como já ocorria com mulheres negras em decorrência da escravização]" (FERREIRA FILHO, p. 22-23, 1994. Grifos nossos.).
} 
dedicadas a diferentes regiões, sinalizando que a agência feminina por meio de associações também foi acionada, a despeito da fundação patriarcal e racista da sociedade brasileira. ${ }^{39}$

Lysie Reis identificou a existência de sociedades de caráter exclusivamente previdenciário de composição feminina na Bahia, como a Sociedade Humanitarista de Senhoras, criada em I89I. Diferentemente das associações mutualistas, as previdenciárias não tinham o vínculo do ofício como um fator aglutinador. A preocupação da Sociedade Humanitarista de Senhoras se dava "no amparo às associadas em situações 'críticas da vida", como uma "moléstia ou qualquer outra causa que a impedisse de conseguir um emprego" (REIS, 20I2, p. 243). Suas associadas primavam pela política de amparo às associadas em ocasião de situações como de doença, viuvez ou desemprego. Dentre os critérios de admissão para a sociedade estava a exigência de serem casadas ou viúvas, requisitos não tão acessíveis às pretas, como apontado acima.

Uma exceção a esta regra de exclusão das mulheres das associações operárias em Salvador se deu com a Sociedade Bolsa de Caridade. Ela foi criada em I872, voltada exclusivamente para os trabalhadores do Arsenal de Guerra da Bahia. Apesar do seu teor civil, ela foi instalada inicialmente na igreja dos órfãos de São Joaquim e tinha uma padroeira, Nossa Senhora do Noviciado. Posteriormente, a associação se abriu para a filiação de operários de outras áreas, devido à extinção dos arsenais. Esta inclusão abriu espaço até para a filiação de mulheres, desde que fossem "senhoras parentas dos sócios”. Mais tarde, a elas foi concedido o direito de votar e ser votada para qualquer cargo da associação (CASTELLUCCI, 20IO, p. 49).

A Bolsa de Caridade integrava esse mapa de rede de associações do Centro Histórico de Salvador. Um dos nomes da Irmandade do Rosário que possivelmente figurou nas suas fileiras foi o de Manuel do Nascimento de Jesus. Segundo Castellucci, ele integrou o Partido Operário, o Club União dos Artistas Republicanos de Pirajá e a Sociedade Protetora dos Desvalidos (CASTELLUCCI, 2008). Na SPD, ele constava

\footnotetext{
39 Sobre a historiografia relativa ao associativismo negro no Brasil, ver DOMINGUES (2007); SILVA;
} XAVIER (20I9). 
como sócio benemérito em I895. ${ }^{40}$ No Rosário, seu nome constou como procurador geral em I890 e I89I ${ }^{41}$ e como escrivão em I892 e I894.

Esta configuração de redes entre as entidades de teor classista, racial, religioso, de gênero e de sociabilidade foi um fenômeno comum em outras partes do país, como vimos em Porto Alegre e em São Paulo. Na Bahia, a adição dos candomblés a esta “constelação associativa” (CASTELLUCCI, 2008, p. I4I) se efetivou não só em Salvador, mas também na cidade de Cachoeira. Segundo o antropólogo Luis Nicolau Parés, no final do século XIX, a Sociedade Monte Pio dos Artistas Cachoeiranos, a Irmandade de São Benedito e a filarmônica Lira Ceciliana formavam uma "rede de instituições" predominantemente negra (PARÉS, 2007, p. 193). Esta rede atuava junto às facções políticas conservadoras e suas respectivas agremiações, como forma de estabelecer uma negociação em torno dos interesses daquela rede de artífices.

O personagem cuja atuação político-social simboliza esta proximidade de associações e irmandades ao candomblé de Cachoeira é José Maria Belchior, ou Zé do Brechó, como era conhecido. Ele foi proprietário dos terrenos da Roça de Cima, candomblé de nação jeje, e presidente do Montepio da cidade (PARÉS, 2007, p. 192). Sua mãe foi vodúnsi ${ }^{42}$ do mesmo terreiro, o que indica que seu filho não era só proprietário daquelas terras, como também tinha ligação religiosa com o candomblé. Sua posição de destaque como proprietário de terras, capitão da Guarda Nacional e atuante na Sociedade Monte Pio, lhe rendeu a nomeação para presidente e procurador do Conselho Filial de Cachoeira do Centro Operário da Bahia (PARÉS, 2007, p. 194). Também localizamos a proximidade de Zé do Brechó de membros da SPD e da Ordem do Rosário. Foi o caso de seu compadre Frederico Roque Guimarães, cuja filha tinha como padrinhos o "feiticeiro" de Cachoeira e o Tenente Manoel Friandes (CAMPOS, 20I8, p. 3I-32).43 Por esse caso, podemos vislumbrar a possibilidade de uma extensão ainda mais ampla desta rede, que atravessava diferentes cidades baianas.

As ligações dos candomblés com o Rosário dos Pretos não se restringiam por gênero. De modo que os jazigos depositados na igreja do Pelourinho revelam a

\footnotetext{
$4^{\circ}$ AINSR. "Relatório de atividades da Sociedade Protetora dos Desvalidos - I895". Caixa I9 Doc OI-G.

${ }^{41}$ AINSR. "Eleição I890". Caixa II Doc 03-K.

${ }^{42}$ Termo que indica filhos(as) de santo da nação jeje, que manifestam a energia do vodun (divindade do candomblé jeje).

43 AINSR. "Listagem de irmãos (I900)". Caixa Io, Doc 5.
} 


\title{
C) HitșTórICA
}

diversidade de casas de candomblé e suas respectivas lideranças próximas à confraria.

Ali

\begin{abstract}
Encontram-se túmulos de figuras emblemáticas do culto afro-brasileiro, como o jazigo da família de Rodolpho Bambocher.44 Seu filho Felisberto Américo Sowzer, ou Benzinho, era filho de Maria Julia Andrade, importante sacerdotisa do candomblé ketu na Bahia. Criado em Lagos, Benzinho veio para o Brasil com o sobrenome Sowzer (Souza). Falecido em I935, foi um dos mais famosos babalorixás do Brasil (V. O. $3^{\text {a }}$. N. SRA. DO ROSÁRIO, 20I8, p. 20).
\end{abstract}

A despeito das orientações de um catolicismo imposto pelas autoridades clericais e de repressões racistas de outras autoridades, naquele espaço a "dupla pertença" (SANTANA, 2013) se consolidou, marcada por devoções afro-baianas que não anulavam outras religiosidades e outros pertencimentos, que traziam consigo a marca compartilhada de uma identidade afro-baiana. Certamente outros registros, materiais ou orais, atestam a frequência de tal fenômeno na região.

Nas correspondências enviadas à Ordem Terceira do Rosário encontramos um indício da existência de uma rede com ampla extensão entre associações negras fora da Bahia. No ano de 1905 foi enviada uma carta da Secretaria da Comissão Glorificadora à Memória de José do Patrocínio, estabelecida no Rio de Janeiro, à igreja do Rosário soteropolitana. O objetivo do órgão era promover os feitos de Patrocínio pela conquista da liberdade da população negra brasileira. Na correspondência em questão, a secretaria solicitava doações para financiar a construção de uma estátua em memória do nacionalmente renomado abolicionista. Segundo os redatores, seu nome "sintetiza todos os esforços, todas as lutas e todas as energias cívicas para a vitória da liberdade de uma raça e engrandecimento do nível moral de um país". A carta parece ser uma cópia padrão, não há assinaturas ou outra inscrição manuscrita e, possivelmente, foi enviada a várias outras associações que a comissão julgou que se interessaria pela causa. 45

\footnotetext{
44 "Rodolpho Martins de Andrade" era o nome "de branco" de Bamboxê, que "é a transcrição brasileira do nome próprio ioruba Bangbose, que significa 'ajuda-me a segurar o oxê' [a ferramenta ritual de Xangô]" (LIMA, Apud. SILVEIRA, 2006, p. 403). O uso do seu nome imposto pelo tráfico juntamente à denominação ioruba (com outra grafia) em sua lápide depositada na Igreja do Rosário é outro sinal da inclusão da herança africana e do legado do candomblé neste templo. Bamboxé também teria participado do processo de feitura de Mãe Aninha (TOBIOBÁ, 2007, p. 266). Para ver outras figuras ligadas aos candomblés e à referida confraria no início do século XIX ver: CASTILLO (2017).

45 "Correspondência da Secretaria da Comissão Glorificadora à Memória de José do Patrocínio", (20/03/1905). Fonte: AINSR. Caixa 23 Doc 02-F.
} 


\section{C) GitistóróRICA}

Ter constado na lista de destinatários da Comissão Glorificadora à Memória de José do Patrocínio revela que a Ordem Terceira integrava as agremiações consideradas relevantes pelas lideranças negras e abolicionistas da capital federal. Logo, ela se destacava quase em âmbito nacional. Não sabemos se os irmãos e irmãs atenderam ao pedido da carta, enviando alguma doação para que fosse construída a estátua de Patrocínio. Mas só a expedição da correspondência já evidencia a tentativa de um estabelecimento de um rosário de associações negras do Brasil no início do século XX, tendo a confraria baiana como uma de suas contas.

\section{Considerações Finais}

Vale ressaltar que, a despeito das críticas à falta de um engajamento por parte da comunidade afro-baiana baseado na condição racial, essa aproximação indica que estes grupos não estavam alheios às causas defendidas pelas associações que eram tidas como organizadas efetivamente pela raça, como era o caso daquelas do Sudeste do país, no início do século XX. Então, mesmo considerando o seu campo de atuação, voltado para o mundo das tradições culturais e religiosas, como uma política de resistência às autoridades e às elites com seus projetos políticos embranquecedores, acreditamos que a Ordem Terceira do Rosário não se manteve alheia às questões que envolviam à comunidade negra para além da cidade de Salvador e da Bahia. Para além das festividades e do carnaval. De todo modo, pensar que a luta pela preservação destas práticas não incluiu a busca por direitos básicos, é avaliar a mobilização e ações políticas dessas comunidades e suas associações sob mentalidade fortemente eurocêntrica.

Assim, como defendeu Butler, é necessário entender que cada luta que emergiu em torno da negritude surgiu "em resposta a diferentes trajetórias e modalidades históricas de exclusão étnica" (BUTLER, 1998, p. 218). Logo, as maneiras de reagir foram também foram diferentes. A constituição de associações e a criação de redes entre elas, cujos critérios não foram apenas as dimensões de classe ou de raça, autoriza-nos a pensar as experiências das associações negras como espaço onde se exercitavam algumas práticas cidadãs. Nessas agremiações mutualistas os soteropolitanos buscavam melhores condições de vida no pós-abolição, em um cenário onde os integrantes do Estado pouco se atentaram para as questões sociais ligadas aos grupos 
marginalizados e aos/às trabalhadores/as. Por vezes, estes grupos se filiaram à classe patronal por questões pragmáticas, almejando conquistar seus direitos por meio da negociação com as elites.

Observamos também que, em certos momentos, sua ação/reação não foi tão alinhada ao interesse dos patrões, tal como ocorreu na greve deflagrada em 1919, que teve como um de seus líderes Tibúrcio Luiz Souto, irmão do Rosário e membro de outras agremiações religiosas e de ofício. Não resta dúvida de que o estabelecimento desta "geografia associativa" nos permitiu identificar e perceber que os irmãos e irmãs do Rosário não estavam alheios às questões mais amplas do debate sobre direitos políticos e sociais da Primeira República. Apesar de constituir um espaço religioso, o engajamento de alguns de seus membros tanto na Ordem quanto nas associações operárias revela que, ali na Igreja do Rosário, os debates profanos deviam ser acalorados, já que muitos dos seus integrantes mantinham essa filiação plural, participando de várias sociedades mutualistas e de candomblés. Ainda assim, o empenho pelo reconhecimento das autoridades religiosas não ficou esquecido, como revela a conquista do título de ordem terceira. Assim, consideramos que constituiu um espaço de disputa e de difusão de ideias em prol da questão social para um segmento expressivo, negro, da sociedade soteropolitana.

Procuramos seguir o caminho sugerido pelo historiador Aldrin Castellucci, de realizar uma "cartografia do associativismo mutualista" em Salvador (CASTELLUCCI, 20I0, p. 74), enfocando Manoel Querino e outros membros mais ou menos conhecidos da Venerável Ordem Terceira do Rosário das Portas do Carmo. Certamente, a ligação foi mais extensa do que aquela que conseguimos traçar até o momento. Contudo, concluímos que, apesar de uma certa decadência das confrarias religiosas ocorrida no final do século XIX, vimos que a Ordem Terceira do Rosário não só se manteve como também se inseriu no movimento de modernização do mutualismo na Bahia, a partir da estreita comunicação entre seus líderes e a disponibilização do seu espaço para eventos das agremiações operárias.

\section{Referências Bibliográficas}


ALBUQUERQUE, Wlamyra. O civismo festivo na Bahia: comemorações públicas do Dois de Julho (I889-I923). Dissertação (Mestrado em História) - Universidade Federal da Bahia, Salvador, 1997.

O jogo da dissimulação: abolição e cidadania negra no Brasil. São Paulo: Companhia das Letras, 2009.

ARAUJO, Diana da Silva. O papel social dos ritos fúnebres nas irmandades negras do Rio Grande do Norte no século XIX. Anais XVIII Semana de Humanidades. UFRN, Junho/20Io.

BATALHA, Claudio H. M. A geografia associativa: associações operárias, protesto e espaço urbano no Rio de Janeiro da Primeira República. In.: AZEVEDO, Elciene... [et al.] (Orgs.). Trabalhadores na cidade: cotidiano e cultura no Rio de Janeiro e em São Paulo, séculos XIX e XX. Campinas: Editora da Unicamp, 2009, pp. 25I-269.

Sociedades de trabalhadores no Rio de Janeiro do século XIX: algumas reflexões em torno da formação da classe operária. In.: Cadernos AEL, v. 6, n. Io/II, I999. BOSCHI, Caio César. Os Leigos e o Poder. Irmandades Leigas e Política Colonizadora em Minas Gerais. São Paulo: Editora Ática, 1986.

BRAGA, Julio. Sociedade Protetora dos Desvalidos: uma irmandade de cor. Salvador: Edições Ianamá, 1987.

BUTLER, Kim. Freedoms Given, Freedoms Won. Afro-brazilians in post-abolition São Paulo and Salvador. New Brunswick: Rutgers University Press, 1998.

CAMPOS, Lucas Ribeiro. Sociedade Protetora dos Desvalidos: mutualismo, política e identidade racial em Salvador (I86I-I894). Dissertação (Mestrado em História) Universidade Federal da Bahia, Faculdade de Filosofia e Ciências Humanas, Salvador, 2018.

CASTELLUCCI, Aldrin. A luta contra a adversidade: notas de pesquisa sobre o mutualismo na Bahia (I832-I930). Revista Mundos do Trabalho, vol.2, n. 4, ago./dez., pp. 40-77, 2010.

Trabalhadores, máquina política e eleições na Primeira República. Tese (Doutorado em História) - Universidade Federal da Bahia, Faculdade de Filosofia e Ciências Humanas, Salvador, 2008. 


\section{G) HitșTórICA}

CASTILLO, Lisa Earl. O Terreiro do Gantois: redes sociais e etnografia histórica no século XIX. Revista de História. São Paulo, n I76, ago. 2017.

CHALHOUB, Sidney. Visões da liberdade: uma história das últimas décadas da escravidão na Corte. São Paulo: Companhia das Letras, 1990.

CHALHOUB, Sidney. Solidariedade e liberdade: sociedade beneficentes de negros no Rio de Janeiro na segunda metade do século XIX. In.: GOMES, Flávio. CUNHA, Olívia Maria Gomes da. Quase-cidadão: histórias e antropologias da pós-emancipação no Brasil. Rio de Janeiro: Editora FGV, 2007, pp. 219-239.

CHALHOUB, Sidney; SILVA, Fernando Teixeira da. Sujeitos no imaginário acadêmico: escravos e trabalhadores na historiografia brasileira desde os anos 1980. Cadernos AEL, Campinas, v. I4, n. 26, 2009, pp. I3-47.

CONCEIÇÃO, Miguel Luiz. Educar para bem servir: entre a Abolição e a República: as elites baianas e a educação de escravos e libertos. In.: PEREIRA, Claudio. (Orgs.). Política, instituições e personagens da Bahia (I850-1930). Salvador: EDUFBA; CEAO, 20I3, pp. $17-42$.

COUTO, Edilece Souza. O arcebispo reformador e os irmãos leigos: notas da biografia de dom Jerônimo Tomé da Silva. Revista Brasileira de História das Religiões. ANPUH, Ano IX, n. 26, pp. 85-Ioo, Setembro/Dezembro de 2016.

DOMINGUES, Petrônio. Movimento Negro Brasileiro: alguns apontamentos históricos. Tempo, n. 23, pp. IOo-I22, julho/2007.

FARIAS, Sara. Irmãos de cor, de caridade e de crença: a Irmandade do Rosário do Pelourinho na Bahia do século XIX. Dissertação (Mestrado em História) Universidade Federal da Bahia, 1997.

FERREIRA FILHO, Heráclito. Salvador das mulheres: condição feminina e cotidiano popular na Belle Époque imperfeita. Dissertação (Mestrado em História) Universidade Federal da Bahia, Salvador, I994.

FRAGA FILHO, Walter. Encruzilhadas da Liberdade: Histórias de escravos e libertos na Bahia (I870-I9I0). Rio de Janeiro: Civilização Brasileira, 2014.

GIL, Tiago Luís; BARLETA, Leonardo Brandão (Coord.). Atlas histórico da América Lusa. Porto Alegre: Ladeira Livros, 2016. 
GINZBURG, Carlo. O nome e o como: troca desigual e mercado historiográfico. In. GINZBURG, Carlo. A micro-história e outros ensaios. Lisboa: Difel; Rio de Janeiro: Editora Bertrand Brasil, 1994, pp. I69-178.

GOMES, Flávio. Negros e política (I888-1937). Rio de Janeiro: Zahar, 2005. Formato eBook Kindle.

GOMES, Flávio. Histórias de Quilombolas: mocambos e comunidades de senzalas no Rio de Janeiro, século XIX. São Paulo: Companhia das Letras, 2006.

GRAHAM, Sandra. Caetana diz não: histórias de mulheres da sociedade escravista brasileira. São Paulo: Companhia das Letras, 2005.

HENRIQUE, Márcio Couto. Irmandades escravas e experiência política no Grão-Pará do século XIX. Revista Estudos Amazônicos. Vol. IV, pp. 3I-5I, 2009.

LEAL, Maria das Graças de Andrade. Manuel Querino entre letras e lutas: Bahia: I85I-1923. São Paulo: Annablume, 2009.

LEITE, Douglas Guimarães. 'Mutualistas, graças a Deus': identidade de cor, tradições e transformações do mutualismo popular na Bahia do século XIX. Tese (Doutorado em História) - Universidade de São Paulo, Faculdade de Filosofia, Letras e Ciências Humanas, São Paulo, 20I7.

MAC CORD, Marcelo. Artífices da cidadania: mutualismo, educação e trabalho no Recife oitocentista. Campinas: Editora da Unicamp, 2012.

MACHADO, Alex. Quando a explicação do divino denuncia os atos humanos: o mistério do incêndio da igreja de Nossa Senhora do Rosário dos Homens Pretos. Freguesia de São Miguel de Alagoas, I8or. CLIO: Revista de Pesquisa Histórica. Vol. 38, pp. 238-316, Jan-Jun, 2020.

MATTOS, Hebe. Das cores do silêncio - significados da liberdade no sudeste escravista. $3^{\mathrm{a}}$ ed. Campinas: Editora Unicamp, 2013.

MATTOSO, Katia M. de Queirós. Bahia, século XIX: uma província no Império. Rio de Janeiro: Nova Fronteira, I992.

MATTOSO, Katia. Ser escravo no Brasil - Séculos XVI-XIX. Petrópolis: Editora Vozes, $2016\left[\mathrm{I}^{\mathrm{a}}\right.$ ed. 1978]. 
MOREL, Marco. A Revolução do Haiti e o Brasil Escravista: o que não deve ser dito. Jundiaí: Paco Editorial, 2017.

MULLER, Liane. As contas do meu rosário são balas de artilharia. Porto Alegre: Editora Pragmatha, 2013.

MULVEY, Patricia A. Black Brothers and Sisters: Membership in the Black Lay Brotherhoods of Colonial Brazil. Luso-Brazilian Review. Vol. I7, No. 2, I980. Pp. 253-279.

NASCIMENTO, Álvaro Pereira. Trabalhadores negros e o "paradigma da ausência": contribuições à História Social do Trabalho no Brasil. Estudos Históricos, Rio de Janeiro, vol. 29, $\mathrm{n}^{0}$ 59, pp. 607- 626, set./dez. 2016.

NEPOMUCENO, Eric Brasil. “Cidadania 'na ponta'”: participação negra nos carnavais cariocas da Primeira República (I889-19I7). Anais do XXVII Simpósio Nacional de História - ANPUH. 2013.

OLIVEIRA, Maria Inês Côrtes. O liberto: o seu mundo e os outros. Salvador, I790/I890. São Paulo: Corrupio, 1988.

PARÉS, Luis Nicolau. A formação do Candomblé: história e ritual da nação jeje na Bahia. $2^{\circ}$ ed. Campinas: Editora da Unicamp, 2007.

PEREIRA, Leonardo Affonso. A cidade que dança: clubes e bailes negros no Rio de Janeiro (I88I-1933). Campinas: Editora da Unicamp; Rio de Janeiro: EdUERJ, 2020.

PINTO, Ana Flávia Magalhães. "De pele escura e tinta preta: a imprensa negra do século XIX (I833-I899)”. Dissertação (Mestrado em História) - Universidade de Brasília, Brasília, 2006.

Fortes laços em linhas rotas: literatos negros, racismo e cidadania na segunda metade do século XIX. Tese (Doutorado em História). UNICAMP, Campinas, 2014.

Imprensa negra no Brasil do século XIX. São Paulo: Selo Negro, 2010.

QUINTÃO, Antonia Aparecida. Irmandades negras: outro espaço de luta e resistência (São Paulo: I870-I890). São Paulo: Anablumme/Fapesp, 2002.

"Lá vem meu parente: as irmandades de pretos e pardos no Rio de Janeiro e em Pernambuco (Século XVIII)”. Tese (Doutorado em História). Universidade de São Paulo, São Paulo, 1997. 
REGINALDO, Lucilene. Irmandades. In. SCHWARCZ, Lilia; GOMES, Flavio (Orgs.).

Dicionário da Escravidão e Liberdade: 50 textos críticos. São Paulo: Companhia das Letras, 2018, pp. 268-274.

- Os Rosários dos Angolas: irmandades de africanos e crioulos na Bahia setecentista. São Paulo: Alameda, 20II.

REIS, João José. De olho no canto: trabalho de rua na Bahia na véspera da abolição. Afro-Ásia, n. 24, pp. 199-242, 2000.

. Ganhadores: a greve negra de I857 na Bahia. São Paulo: Companhia das Letras, 2019.

"Identidade e Diversidade Étnicas nas Irmandades Negras no Tempo da Escravidão". Tempo, Rio de Janeiro, vol. 2, n 3, pp. 7-33, 1996.

. Rebelião Escrava no Brasil: a história do levante dos malês, I835. São Paulo: Companhia das Letras, 1985.

REIS, João José; SILVA, Eduardo. Negociação e Conflito: a resistência negra no Brasil escravista. São Paulo: Companhia das Letras, 1989.

REIS, Lysie. A liberdade que vem do ofício: práticas sociais e cultura dos artífices da Bahia do século XIX. Salvador: EDUFBA, 2012.

RIBEIRO, Jonatas Roque. Escritos da liberdade: trajetórias, sociabilidade e instrução no pós-abolição sul-mineiro (I888-I930). Dissertação (Mestrado em História). UNICAMP, Campinas, 2016.

RUSSELL-WOOD, A. J. R. Black and Mulatto Brotherhoods in Colonial Brazil: A Study in Collective Behavior. The Hispanic American Historical Review. Duke University Press. Vol. 54, No. 4 (Nov., 1974). Pp. 567-602.

SAMPAIO, Patrícia Melo. Escravidão e Liberdade na Amazônia: notas de pesquisa sobre o mundo do trabalho indígena e africano. Anais do $3^{\circ}$ Encontro Escravidão e Liberdade no Brasil Meridional. 2007.

SANTANA, Analia, A participação política das mulheres na Irmandade de Nossa Senhora do Rosário dos Homens Pretos do Pelourinho (I969-200I). Dissertação (Mestrado em História) - Universidade do Estado da Bahia, Salvador, 2013. 


\section{C) HitșTórICA}

SANTIROCCHI, Ítalo Domingos. Uma questão de revisão de conceitos: Romanização

- Ultramontanismo - Reforma. Temporalidades - Revista Discente do Programa de PósGraduação em História da UFMG, vol. 2, n 2, p. 24-33, Agosto/Dezembro de 2010.

SANTOS, Claudefranklin. "A festa de São Benedito em Lagarto-SE (I77I-I928): limites e contradições da romanização". Tese (Doutorado em História) - Universidade Federal de Pernambuco, Recife, 2013.

SANTOS, Mariana de Mesquita. Pelas Contas do Rosário: cidadania na Irmandade de Nossa Senhora do Rosário dos Homens Pretos do Pelourinho no Pós-Abolição (Salvador, I888-1930). Dissertação (Mestrado em História) - Universidade de Brasília, Brasília, 2018.

SCARANO, Julita. Devoção e escravidão: a Irmandade de Nossa Senhora do Rosário dos Pretos no Distrito Diamantino no Século XVIII. São Paulo, Companhia Editora Nacional, 1975 .

SILVA, Maria da Conceição Barbosa da Costa e. O Montepio dos Artistas: elo dos trabalhadores em Salvador. Salvador: Secretaria da Cultura e Turismo do Estado da Bahia; Fundação Cultural; EGBA, 1998.

SILVA, Lúcia Helena Oliveira; XAVIER, Regina Célia Lima. Historicizando o associativismo negro: contribuições e caminhos da historiografia. Mundos do Trabalho, V. II, pp. I-I5, 2019.

SILVEIRA, Renato da. O Candomblé da Barroquinha: processo de constituição do primeiro terreiro baiano de keto. Salvador: Edições Maianga, 2006.

SANTOS, João Batista dos. 2I Cartas e um Telegrama de Mãe Aninha a suas filhas Agripina e Filhinha, I935-I937. Afro-Ásia, 36, pp. 265-310, 2007.

SANTOS, Jocélio Teles dos. De pardos disfarçados a brancos pouco claros: classificações raciais no Brasil dos séculos XVIII-XIX. Afro-Ásia, 32, pp. II5-I37, 2005.

SOARES, Mariza de Carvalho. Devotos da Cor. Rio de Janeiro: Civilização Brasileira, $200 I$.

STASI, Lucas Nunes. "Expressões Leigas da Fé Católica: irmandades religiosas na freguesia de Santana em Salvador (I876-I926)”. Dissertação (Mestrado em História) Universidade Federal da Bahia, Salvador, 2017. 
VALIM, Patrícia. "Da Sedição dos Mulatos à Conjuração Baiana de I798: a construção de uma memória histórica”. Dissertação (Mestrado em História) - Universidade de São Paulo, São Paulo, 2007.

VENERÁVEL ORDEM TERCEIRA DO ROSÁRIO DE NOSSA SENHORA ÀS PORTAS DO CARMO. Irmandade do Rosário dos Pretos: quatro séculos de devoção. Salvador: Secretaria de Cultura; IPAC; Fundação Pedro Calmon [et al.], 2018.

VIANA, Larissa. O idioma da mestiçagem: as irmandades de pardos na América Portuguesa. Campinas: Editora da UNICAMP, 2007.

Recebido em: 30 de abril de 202I

Aceito em: 2I de julho de 202I 